\title{
The Collapse of the Alto Río Building during the 27 February 2010 Maule, Chile, Earthquake
}

\author{
Cheng Song, ${ }^{\text {a) }}$ Santiago Pujol, ${ }^{\text {a) }}$ M.EerI, and Andrés Lepage, ${ }^{\text {b) }}$ M.EerI
}

The Alto Río Building, a 15-story building located in Concepción, Chile, collapsed during the 2010 Maule earthquake. Construction of the building was completed in 2009 following the Chilean building code of 1996. The building was provided with reinforced concrete structural walls (occupying nearly $7 \%$ of the floor area) to resist lateral and vertical loads. The walls failed in the first story, causing the overturning of the entire building. This paper provides detailed field observations and discusses plausible causes of the collapse. [DOI: 10.1193/ 1.4000036]

\section{INTRODUCTION}

The 27 February 2010 Maule, Chile, earthquake $\left(M_{w}=8.8\right.$; USGS 2010) caused severe damage in Concepción, a city located $105 \mathrm{~km}$ (65 miles) from the estimated epicenter $\left(35.909^{\circ} \mathrm{S}, 72.733^{\circ} \mathrm{W}\right.$; USGS 2010$)$. Among approximately 100 buildings with ten or more stories, six buildings were damaged beyond repair and one building (Alto Río) collapsed completely. Press reports indicated that approximately 87 persons were in the building at the time of the collapse. Of these, 79 were reported to have been rescued alive.

Construction of the Alto Río Building was completed in 2009 following drawings reported to comply with the Chilean building code of 1996 (NCh433.Of96; INN 1996). The Chilean building code referred to the Building Code Requirements for Structural Concrete published by the American Concrete Institute in 1995 (ACI 318 1995), but stated explicitly that requirements for confinement of boundary elements in structural walls were not mandatory.

The collapse of the building poses a critical question: Are the requirements for confinement of boundary elements sufficient to prevent the collapse of similar structures elsewhere?

As part of an effort to understand the causes of the collapse, the writers participated in an inspection of the remains of the Alto Río Building on 29 November 2010. The information obtained in the field and analysis results are used to evaluate hypotheses about the causes of the collapse.

a) School of Civil Engineering, Purdue University, 550 Stadium Mall Drive, West Lafayette, IN 47907.

b) Department of Architectural Engineering, The Pennsylvania State University, University Park, PA 16802. 


\section{DESCRIPTION OF THE ALTO RÍO BUILDING}

The Alto Río Building (Figure 1) was located in Concepción $\left(36^{\circ} 49^{\prime} 40.5^{\prime \prime} \mathrm{S}, 73^{\circ} 3^{\prime}\right.$ $\left.42.5^{\prime \prime} \mathrm{W}\right), 0.6 \mathrm{~km}(0.4 \mathrm{miles})$ away from the Bío-Bío River. The building was founded on alluvial deposits.

The building had 15 stories aboveground, 2 stories underground, and a typical floor plan with rectangular shape (Figure 2). It was founded on an $800 \mathrm{~mm}$ (31.5 in.) thick mat foundation. The longitudinal axis of the typical floor plan made an angle of approximately 27 degrees (counterclockwise) with the geographical north-south axis and will be referred to as the north-south axis of the building.

Along its longitudinal axis, the building plan measured nearly $40 \mathrm{~m}(131 \mathrm{ft})$. Along its short (or transverse) axis the building plan was approximately $12 \mathrm{~m}$ (39 ft) long. These overall plan dimensions remained nearly constant from the first story to the twelfth story. The thirteenth, fourteenth, and fifteenth stories had the same width but were shorter in the longitudinal direction. The lengths of the thirteenth, fourteenth, and fifteenth stories were approximately $32 \mathrm{~m}(105 \mathrm{ft}), 24.5 \mathrm{~m}(80 \mathrm{ft})$, and $19.5 \mathrm{~m}(64 \mathrm{ft})$, respectively. These upper three stories were offset with respect to one another so that the west facade of the building appeared to have steps climbing to the south end of the building. The total building height (for 15 stories) was approximately $38 \mathrm{~m}(125 \mathrm{ft})$, with a typical story height of $2.52 \mathrm{~m}(8.3 \mathrm{ft})$. The first story height was $3.06 \mathrm{~m}(10 \mathrm{ft})$. The underground stories were used for parking and had a height of $2.52 \mathrm{~m}(8.3 \mathrm{ft})$ each.

The structural system of the building consisted of an array of reinforced concrete structural walls and pilasters. Figure 2 shows the layout of the structural walls and pilasters shown in drawings dated November 2006. The typical wall thickness was $200 \mathrm{~mm}$ (8 in.). Reinforced concrete flat slabs acted as horizontal diaphragms connecting the structural walls at each floor. The typical thickness of the floor slabs was $150 \mathrm{~mm}(6 \mathrm{in}$.).

Typical wall reinforcement consisted of two layers of $\Phi 10 \mathrm{~mm}$ or $\Phi 8 \mathrm{~mm}$ bars spaced at $200 \mathrm{~mm}$ (8 in.) in the vertical and horizontal directions. At wall boundaries and intersections

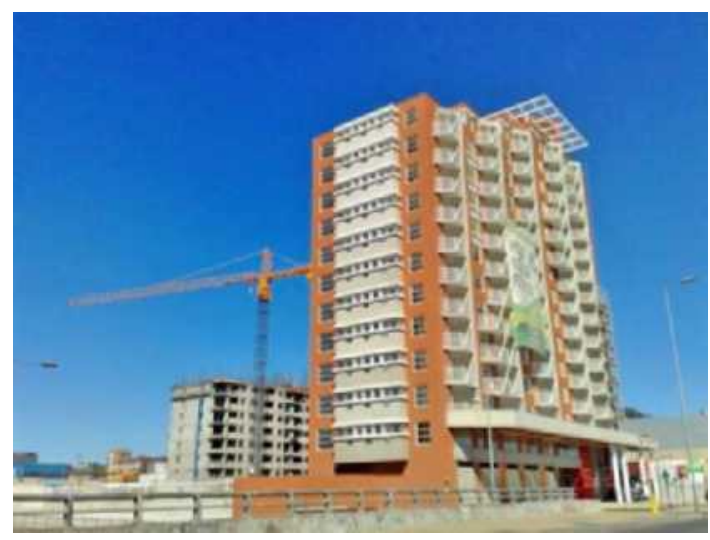

Figure 1. The Alto Río Building before collapse (view from northwest). Taken from http://www. chw.net/foro/off-topic-f16/309633-edificio-alto-rio-Concepcion-antes-despues.html. 


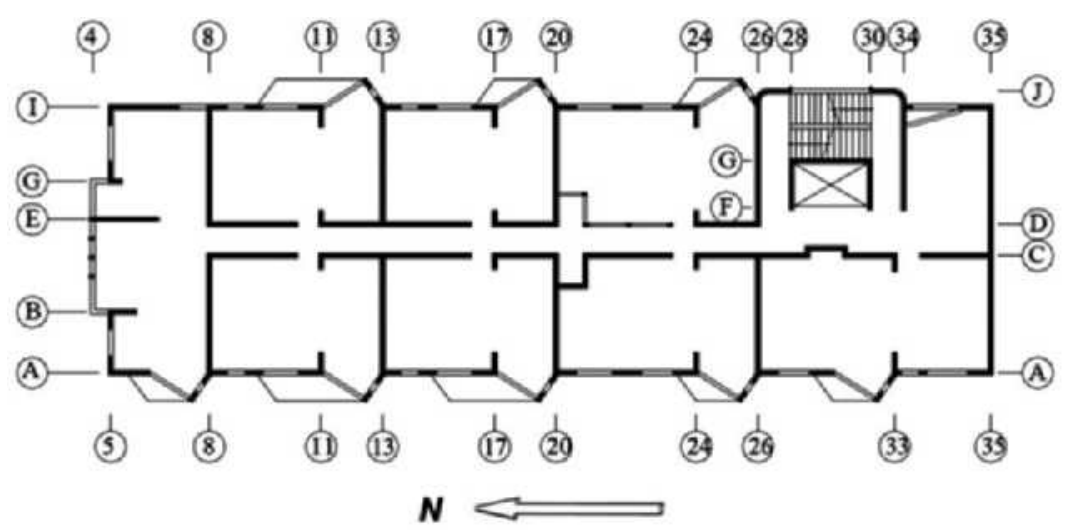

(a)

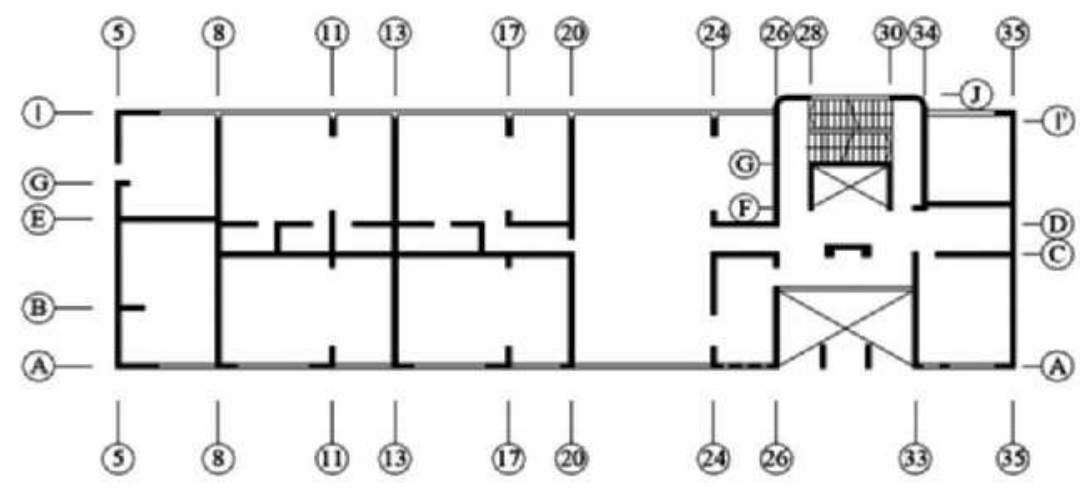

(b)

Figure 2. (a) Typical (second to twelfth) story plan view and (b) first-story plan view.

of wall segments, four to five vertical bars with diameters ranging from $\Phi 16 \mathrm{~mm}$ to $\Phi 25 \mathrm{~mm}$ were added. These bars are referred to as "main boundary reinforcement" in this paper.

The ratio of the cross-sectional area of wall to typical floor area was approximately $3 \%$ for wall segments oriented in the longitudinal direction and $4 \%$ for wall segments oriented in the transverse direction. The ratio of total cross-sectional wall area to floor area was approximately $7 \%$. These numbers were computed using cross-sectional areas of pilasters.

The elevations of walls along axes 8,13 , and 20 were U-shaped (Figure 3 ). In the first story, these walls were continuous (except for the wall along axis 20 , which had a $0.6 \mathrm{~m}(2 \mathrm{ft})$ perforation between axes $\mathrm{C}$ and D; Figure 2) and ran from axis A to axis $\mathrm{I}^{\prime}$ (which was $0.4 \mathrm{~m}$ $(1.3 \mathrm{ft})$ to the west of axis I). In the second story, each of these walls was divided in two segments by a $1.2 \mathrm{~m}(4 \mathrm{ft})$ wide central hallway. One segment ran from axis A to axis $\mathrm{C}$. The other segment ran from axis D to axis I (not $\mathrm{I}^{\prime}$ ), with the exterior $0.4 \mathrm{~m}$ of the wall not being supported by a wall underneath. This $0.4 \mathrm{~m}(1.3 \mathrm{ft})$ wall segment ran from axis I to axis $\mathrm{I}^{\prime}$ and acted as a connection between the wall and the east facade of the building, a grid of reinforced concrete pilaters and spandrels that did not reach the ground (Figure 3, axis I). The elevation of the wall along axis 35 was rectangular and had no openings. Two separate walls, 

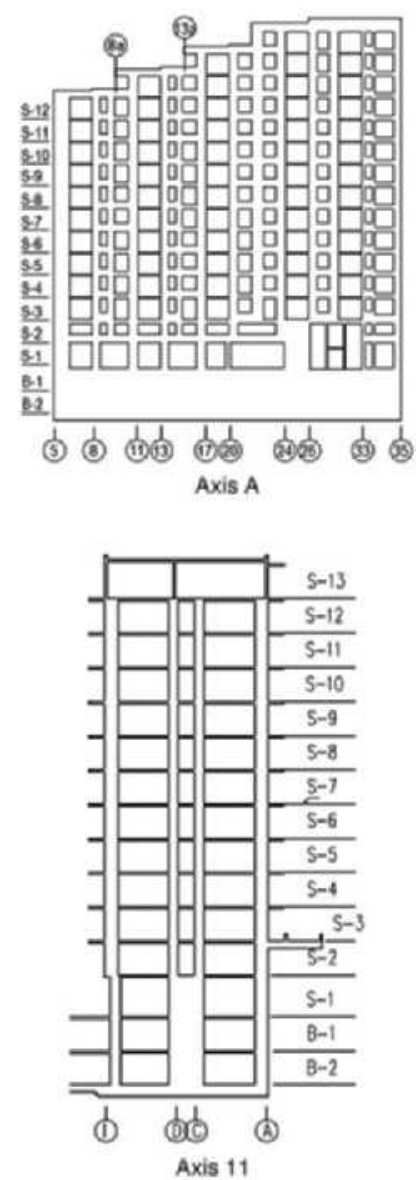

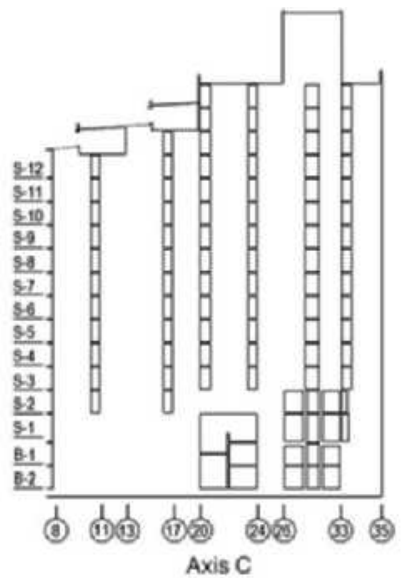

(a)

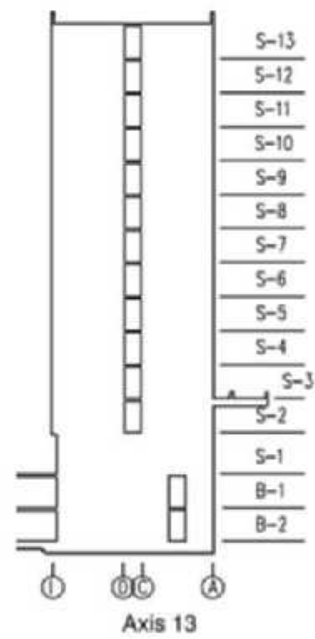

(b)
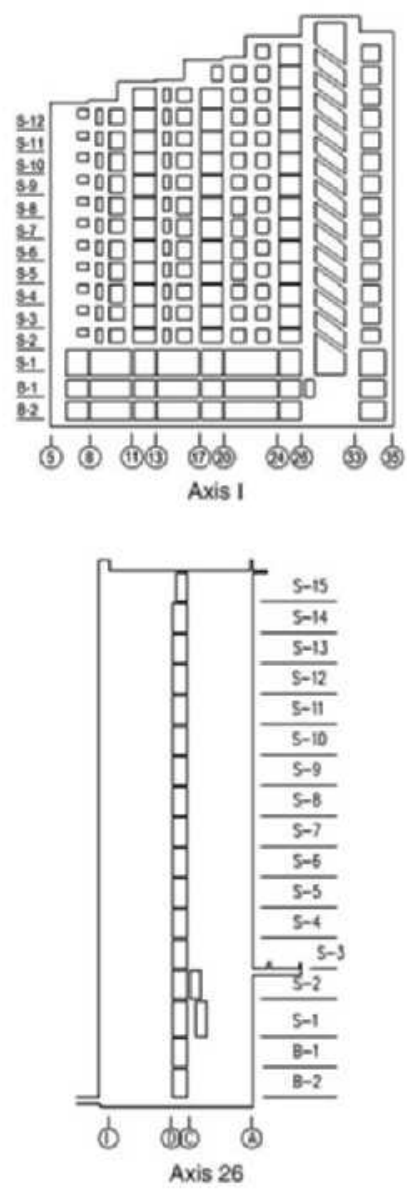

Figure 3. Elevation views: (a) NS elevations (view from west) and (b) EW elevations (view from north).

approximately $5 \mathrm{~m}(16 \mathrm{ft})$ long, were located on axis 26 . Another $5 \mathrm{~m}$ wall was located on axis 34. In the longitudinal direction, most of the walls were located along axes $\mathrm{C}$ and $\mathrm{D}$.

Normal-weight concrete was used to construct the building. Its specified cylinder compressive strength was approximately $f_{c}^{\prime}=25 \mathrm{MPa}(3,600 \mathrm{psi})$ for the second and lower stories ${ }^{1}$. Above the second story, the specified compressive strength was

\footnotetext{
${ }^{1}$ In Chile, concrete compressive strength is specified in terms of results from tests of cubes. The values reported here were obtained assuming that cylinder strength is approximately 0.8 times cube strength.
} 
Table 1. Concrete material properties

\begin{tabular}{lccc}
\hline \hline & & \multicolumn{2}{c}{ Compressive strength MPa (psi) } \\
\cline { 3 - 4 } Type of specimens & Number of samples & Mean & Standard deviation \\
\hline Concrete cores $^{1}$ & 23 & $47(6,800)$ & $6(870)$ \\
\hline \hline
\end{tabular}

${ }^{1}$ Core samples were extracted from the building after the 2010 earthquake. Core dimensions are approximately $100 \mathrm{~mm}$ (4 in.) by $200 \mathrm{~mm}(8 \mathrm{in}$.$) .$

Table 2. Steel material properties

\begin{tabular}{|c|c|c|c|c|c|c|c|}
\hline \multirow[b]{2}{*}{$\begin{array}{l}\text { Type of } \\
\text { specimens }\end{array}$} & \multirow[b]{2}{*}{$\begin{array}{l}\text { Number of } \\
\text { samples }\end{array}$} & \multicolumn{2}{|c|}{$\begin{array}{l}\text { Yield stress }{ }^{1} \\
\text { MPa (ksi) }\end{array}$} & \multicolumn{2}{|c|}{$\begin{array}{l}\text { Ultimate stress }{ }^{1} \\
\text { MPa (ksi) }\end{array}$} & \multicolumn{2}{|c|}{ Elongation $^{2}(\%)$} \\
\hline & & Mean & $\begin{array}{l}\text { Standard } \\
\text { deviation }\end{array}$ & Mean & $\begin{array}{l}\text { Standard } \\
\text { deviation }\end{array}$ & Mean & $\begin{array}{l}\text { Standard } \\
\text { deviation }\end{array}$ \\
\hline Steel bars ${ }^{3}$ & 27 & $480(70)$ & $42(6)$ & $720(105)$ & $31(4.5)$ & 17.4 & 2.3 \\
\hline
\end{tabular}

${ }^{1}$ Specified values: $f_{y}=420 \mathrm{MPa}(60 \mathrm{ksi}), f_{u}=630 \mathrm{MPa}(90 \mathrm{ksi})$.

${ }^{2}$ Measured over a $200 \mathrm{~mm}(8 \mathrm{in}$.) gage length.

${ }^{3}$ Bars tested were cut from the building after the 2010 earthquake.

$f_{c}^{\prime}=20 \mathrm{MPa}(2,900 \mathrm{psi})$. Concrete cores with a diameter of $100 \mathrm{~mm}$ (4 in.) and heights of approximately $200 \mathrm{~mm}$ (8 in.) were obtained from structural walls after the earthquake by IDIEM (2010). Tests of these cores (Table 1) indicated that the mean compressive strength of the concrete was approximately $47 \mathrm{MPa}$ (6,800 psi; IDIEM 2010). The strengths of cores obtained from lower stories were not consistently different from the strengths of cores from higher stories.

The steel reinforcement, specified to meet Chilean Standard A630-420H (INN 2006), had a specified yield stress of $f_{y}=420 \mathrm{MPa}(60 \mathrm{ksi})$ and a specified ultimate stress of $f_{u}=630 \mathrm{MPa}(90 \mathrm{ksi})$. Twenty-seven samples of steel bars were obtained from the structure and tested in tension after the earthquake (IDIEM 2010). The test results are listed in Table 2. The mean yield stress measured in these tests was $480 \mathrm{MPa}$ (70 ksi), and the mean ultimate stress was $720 \mathrm{MPa}$ (105 ksi; IDIEM 2010). The mean elongation at fracture, measured over a $200 \mathrm{~mm}$ (8 in.) gage length, was $17.4 \%$.

\section{MEASURED GROUND MOTION}

The 27 February 2010 Maule, Chile, earthquake had a moment magnitude of 8.8 (USGS 2010). The estimated hypocenter $\left(35.909^{\circ} \mathrm{S}\right.$ and $72.733^{\circ} \mathrm{W}$, depth $=35 \mathrm{~km}(22$ miles $\left.)\right)$ was located $105 \mathrm{~km}$ (65 miles) northeast of the city of Concepción (USGS 2010). Two strongmotion stations recorded the ground motion in the city of Concepción. One was located at Colegio Inmaculada Concepción $\left(36.8281^{\circ} \mathrm{S}, 73.0483^{\circ} \mathrm{W}\right.$; JST-JICA 2010), approximately $1.1 \mathrm{~km}(0.7$ miles $)$ from Alto Río, and the other was located at Colegio San Pedro $\left(36.8443^{\circ} \mathrm{S}\right.$, $73.1087^{\circ} \mathrm{W}$ ), which is on the other side of the Bío-Bío River and approximately $4.7 \mathrm{~km}$ (2.9 miles) from Alto Río. Peak horizontal ground accelerations of $0.40 \mathrm{~g}$ and $0.65 \mathrm{~g}$ were reported for stations Colegio Inmaculada Concepción and Colegio San Pedro, 
respectively (Boroschek et al. 2010). The ground motion recorded at station Colegio Inmaculada Concepción is deemed more representative of the motion experienced at Alto Río because this site is closer, and its soil conditions are more likely to be similar to those in Alto Río. A study by Ramírez and Vivallos (2009) shows that both Alto Río and Colegio Inmaculada Concepción are founded on soils with "dominant periods" (for small-amplitude vibrations) between $1 \mathrm{~s}$ and $1.4 \mathrm{~s}$. These soils are silty sand deposits from the Bío-Bío River with an average standard penetration test (SPT) count of 40 in the upper $15 \mathrm{~m}(50 \mathrm{ft})$.

Ground accelerations were recorded in three directions (longitudinal, vertical, and transverse) with the azimuth of the longitudinal axis of the strong-motion equipment being 60 degrees. The longitudinal direction of the equipment nearly coincides with the transverse (east-west) direction of the Alto Río Building.

The published peak ground accelerations (PGA) at Colegio Inmaculada Concepción are $0.4 \mathrm{~g}$ in the longitudinal direction and $0.3 \mathrm{~g}$ in the transverse direction (Boroscheck et al. 2010). The published peak ground velocities (PGV) are $0.67 \mathrm{~m} / \mathrm{s}(26 \mathrm{in.} / \mathrm{s})$ in the longitudinal direction and $0.52 \mathrm{~m} / \mathrm{s}(20 \mathrm{in} . / \mathrm{s})$ in the transverse direction (Boroschek et al. 2010). Descriptions of measured ground acceleration histories and computed response spectra are presented in Appendix A.

\section{FIELD SURVEY}

The information presented here was obtained from several sources: a field survey conducted on 29 November 2010; a report containing photographs taken the day after the collapse (IDIEM 2010); photographs taken by G. Alarcón on 29 March 2010, 2 November 2010, 29 November 2010; and photographs taken by E. Fierro and A. Iruretagoyena on 16 March 2010. All these sources were used because rescue operations and field investigations requested by the Chilean Ministry of Public Works altered the site through a number of interventions. The area affected most by the interventions was the south end of the building (between axes 24 and 35).

The Alto Río Building (Figure 4a) was the only building with more than three stories that suffered total collapse during the 2010 Maule Earthquake. The building overturned toward the east, rotating about the longitudinal axis of the building in the first story (Figure $4 \mathrm{~b}$ ). During the collapse, the building penetrated the slabs of underground parking spaces, which had a larger floor plan (extending further to the east) than the aboveground stories. Where it met an underground wall oriented in the NS direction, the building split in two (Figure 4).

Walls in the first story failed along cracks that joined the ends of lap slices located in the first story. As the building collapsed, parts of the first-story walls that remained attached to the upper stories rotated approximately 90 degrees, with the ceiling of the first story becoming nearly vertical (Figure 5). The structure shifted as much as $0.8 \mathrm{~m}(2.6 \mathrm{ft})$ toward the south, and the east walls penetrated the basement (Figure 5). Both splice failures and bar fractures were observed on the west side of the first story. Bond failures were observed in bar splices of $\Phi 8 \mathrm{~mm}, \Phi 10 \mathrm{~mm}$, and $\Phi 25 \mathrm{~mm}$ bars. Locations where splice failures and bar fractures were observed in the first story are shown in Figure 6. 


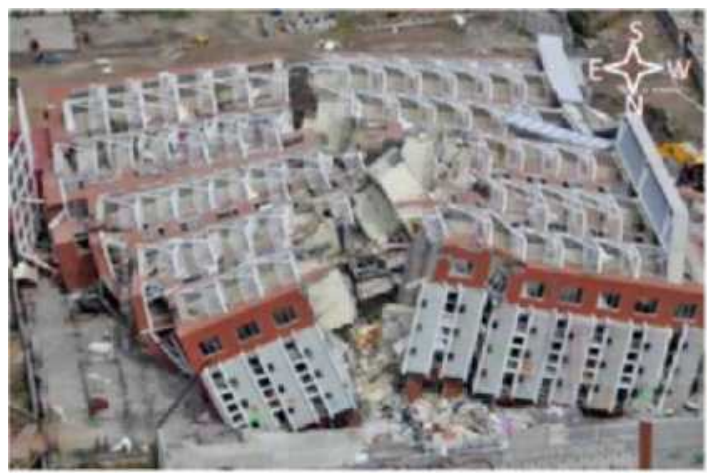

(a)

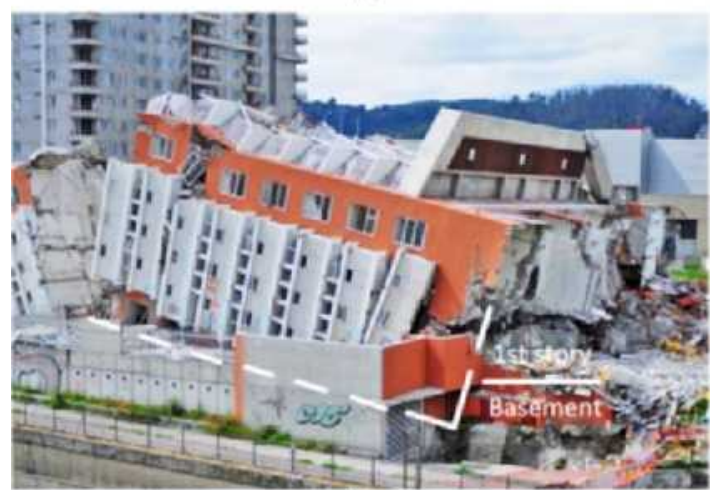

(b)

Figure 4. General photos for the Alto Río Building: (a) the Alto Río building after collapse (from http://skyscraperpage.com/cities/?buildingID=85186); (b) the damage view from north.

Failure surfaces observed along axes 5 to 20 (on 29 November 2010) are shown in Figure 7. Detailed descriptions of the damage observed along each axis are presented in the following sections.

\section{DAMAGE ALONG AXIS 5}

On the northwest side of the building, the wall along axis 5 failed at the base of the first story. The failure surface was horizontal from axis A to axis B, and ascended gradually from axis $B$ to the top of $1.5 \mathrm{~m}$ (60 in.) lap splices near axis $\mathrm{C}$ (Figure 8).

Bar fractures were observed in $\Phi 10 \mathrm{~mm}$ reinforcing bars in the wall web between axes $\mathrm{A}$ and $\mathrm{C}$. In the wall flanges along axes A and B, bar fracture was observed in $\Phi 18 \mathrm{~mm}$ bars. The west end of the wall did not show signs of damage related to compression or shear, but splitting cracks were observed along vertical reinforcement layers (Figure 9).

The east ends of first-story walls penetrated into the basement during collapse. The ceiling of the first story rotated approximately 90 degrees (clockwise if observed from the south) and fell approximately $4 \mathrm{~m}(13 \mathrm{ft})$ to the west of axis $\mathrm{I}$. 


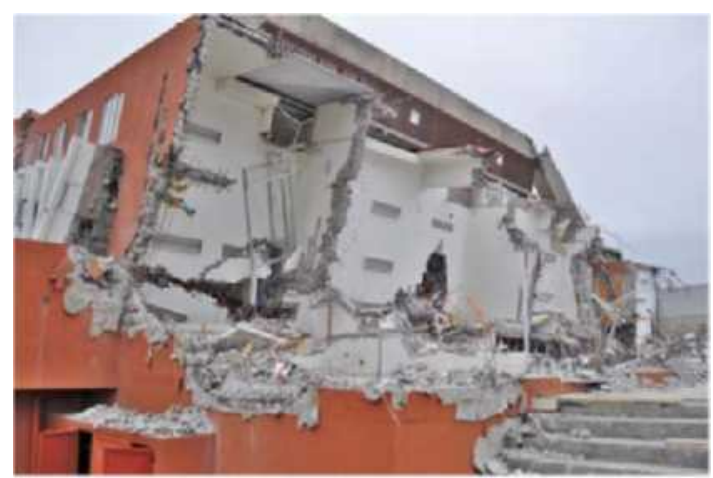

(a)

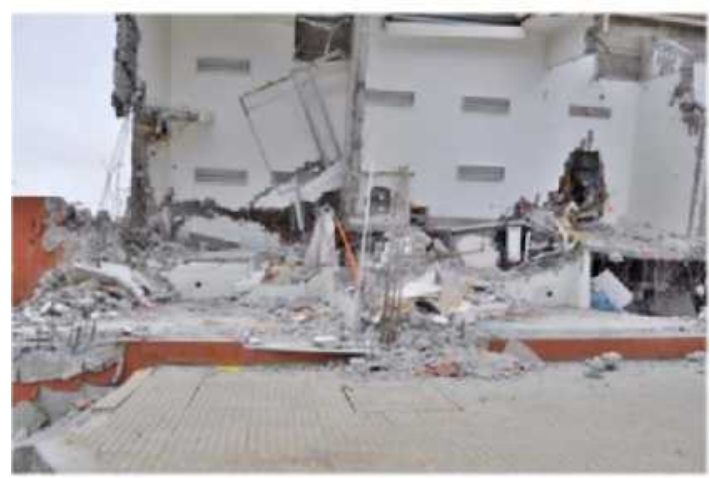

(b)

Figure 5. Damage photos for the first story: (a) damage in the first story (view from northwest); (b) observed shift of walls toward the south (view from west). Photo credit: E. Fierro and A. Iruretagoyena.

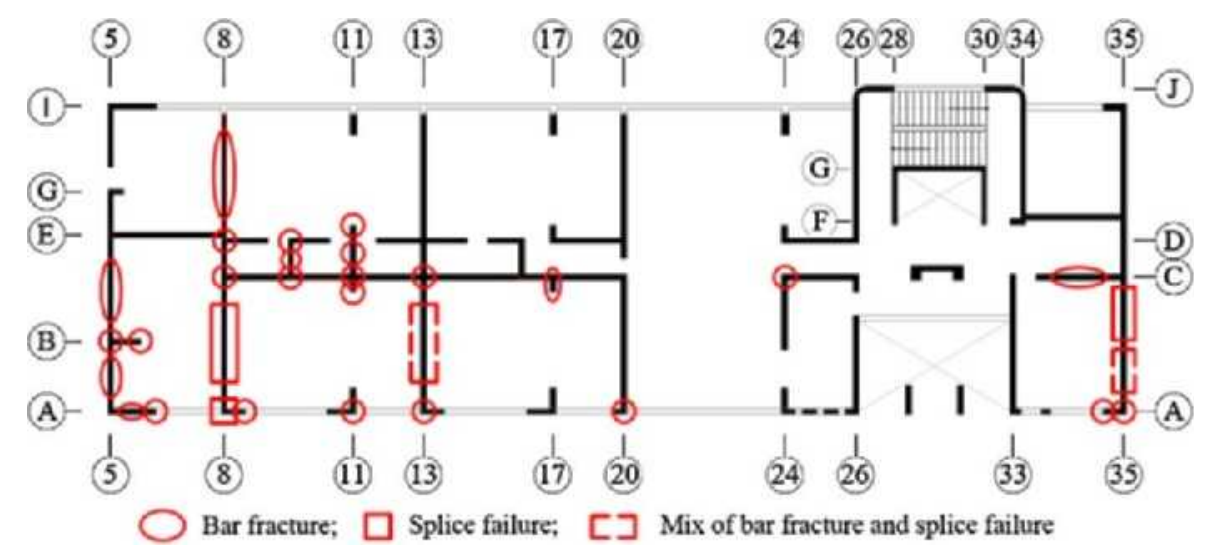

Figure 6. Observed locations of splice failures and bar fractures in the first story (walls without marks could not be inspected). 

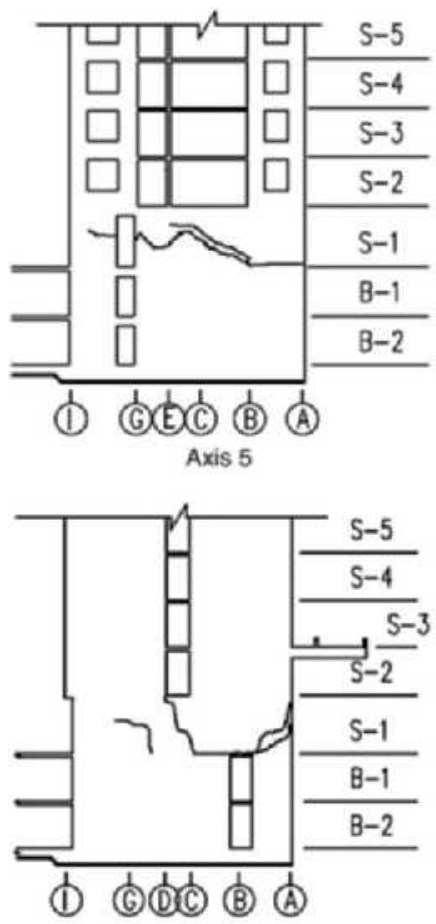

Axis 13

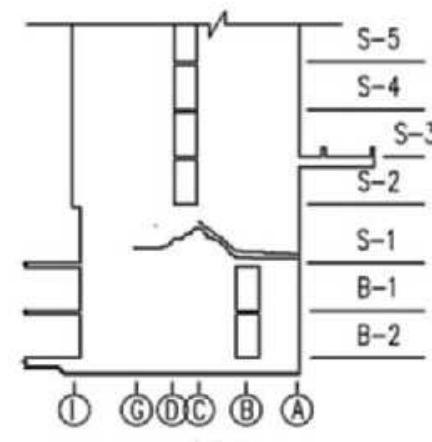

Axis 8

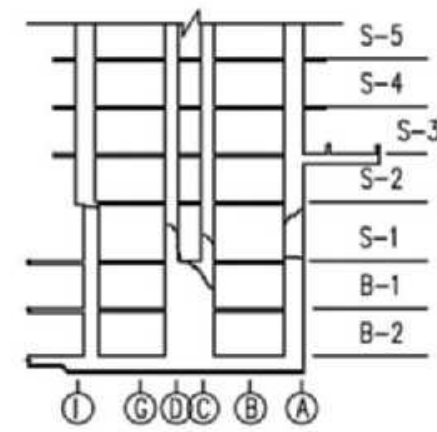

Axis 17

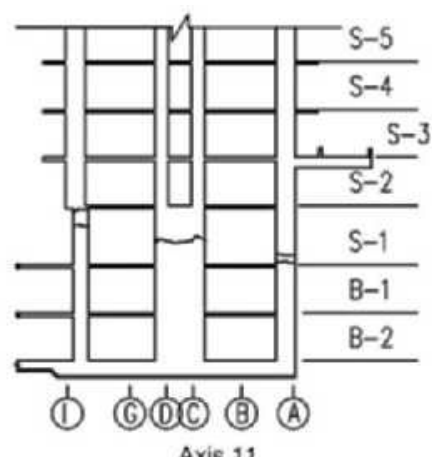

Axis 11

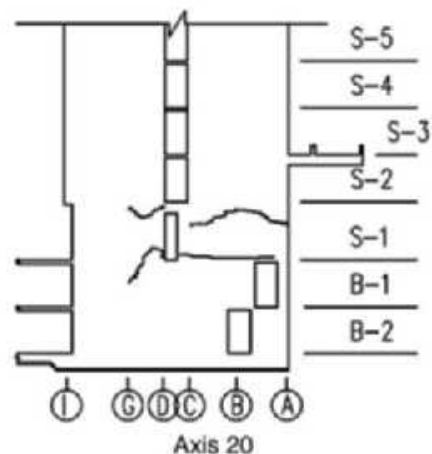

Axis 20

Figure 7. Failure surfaces visible on November 2010 (view from north).

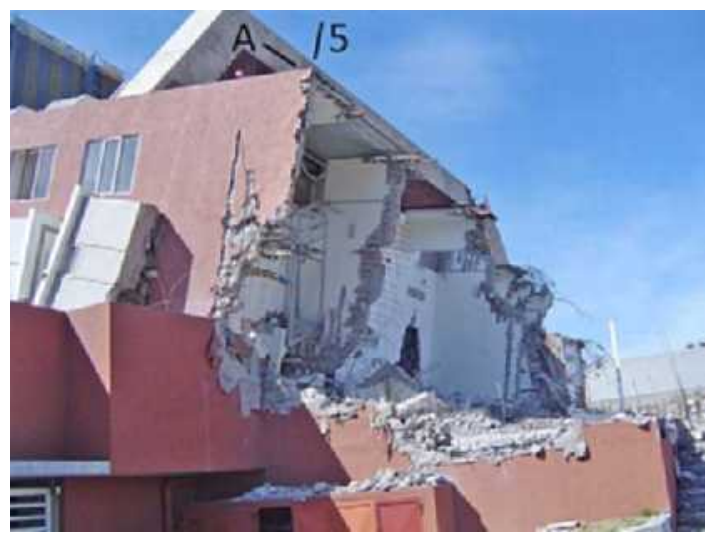

Figure 8. Wall along axis 5, 29 March 2010. Photo credit: G. Alarcón. 


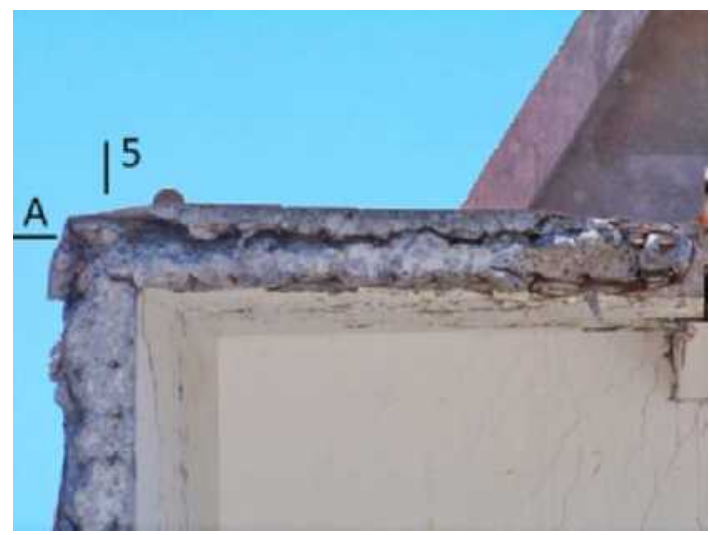

Figure 9. Splitting cracks in wall segments.

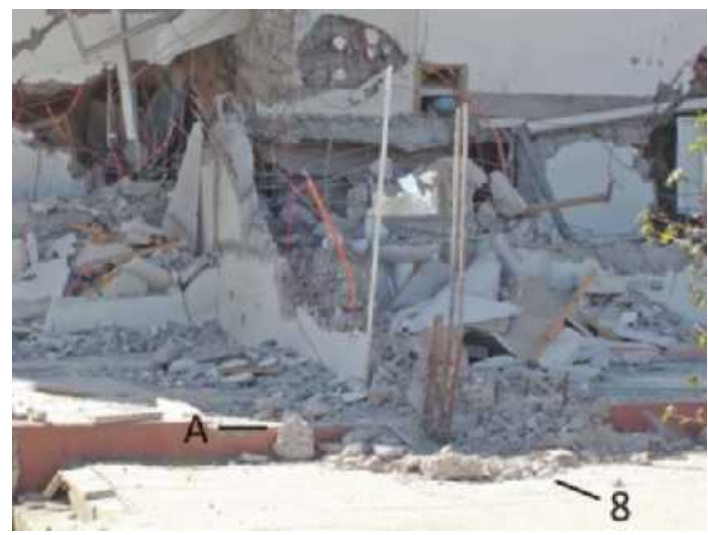

Figure 10. Wall along axis 8 (two of the vertical bars in the foreground had been cut for testing), 29 March 2010.

\section{DAMAGE ALONG AXIS 8}

On the west side of the building, the wall along axis 8 failed along a nearly horizontal surface between axes A and B. The failure surface ascended from axis B to axis C, to reach a height of $1.7 \mathrm{~m}$ (68 in.) at the top end of lap splices of $\Phi 25 \mathrm{~mm}$ bars at C (Figure 10). From axis $C$ to axis D, the failure surface descended to reach the top end of lap splices of $\Phi 22 \mathrm{~mm}$ bars at D, approximately $1.3 \mathrm{~m}$ (50 in.) above ground. Both bar fractures and splice failures were observed in the wall web between axes A and C. In the flange 


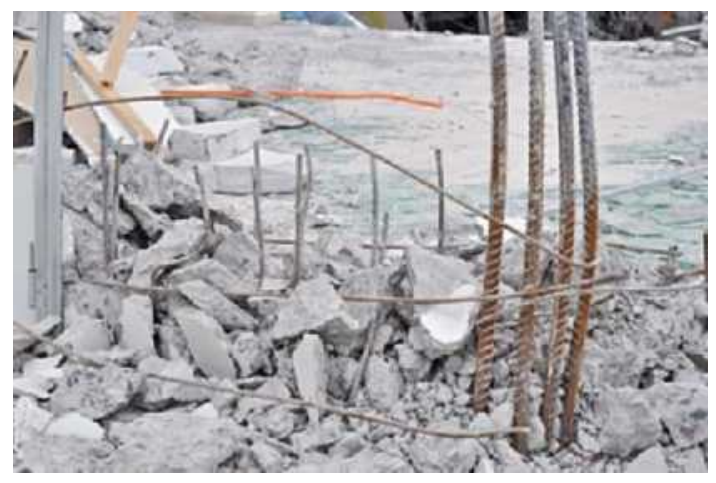

Figure 11. Wall at axes $A$ and 8 (base of the first story), 16 March 2010. Photo credit: G. Alarcón.

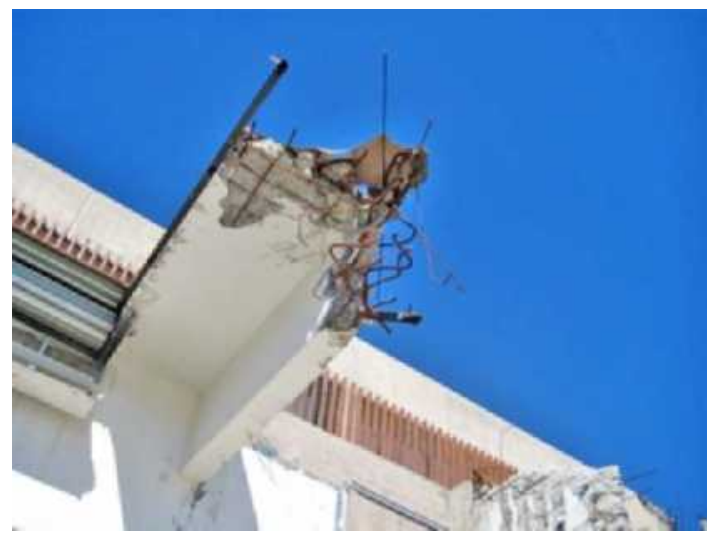

Figure 12. Pilaster at axes A and 11 (top of the first story), 29 November 2010.

along axis A, bar fracture was observed in $\Phi 16 \mathrm{~mm}$ bars and bond failure was observed in bar splices of $\Phi 25 \mathrm{~mm}$ bars (Figures 10 and 11).

\section{DAMAGE ALONG AXIS 11}

In the first story, axis 11 had two pilasters (at A and $\mathrm{I}^{\prime}$ ) and a short wall in the center of the building (between $\mathrm{C}^{\prime}$ and $\mathrm{F}$ ). The west pilaster failed near its base at the bottom of lap splices of four $\Phi 16 \mathrm{~mm}$ bars at node A-11 (Figure 12). The bottom $0.3 \mathrm{~m}$ to $0.4 \mathrm{~m}$ (1 ft to $1.3 \mathrm{ft}$ ) of the pilaster appeared to have disintegrated. The pilaster at axis I' failed at its connection with a similar (but offset) pilaster in the second story. 


\section{DAMAGE ALONG AXIS 13}

On the west side of the building, the wall along axis 13 failed approximately $1 \mathrm{~m}(3.3 \mathrm{ft})$ above the base of the first story at axis A near the end of bar splices. The failure surface descended from axis A, reaching ground level between $\mathrm{A}$ and $\mathrm{B}$. From that point to $\mathrm{C}$, it remained horizontal.

Both splice failures and bar fractures were observed in the wall web between axes A and $\mathrm{C}$. In the flange along axis A, bar fracture was observed in $\Phi 22 \mathrm{~mm}$ bars.

The segment of wall that remained attached to the upper stories had inclined cracking.

\section{DAMAGE ALONG AXIS 17}

Pilasters near axis I were observed to have failed near the top of the first story.

\section{DAMAGE ALONG AXIS 20}

On the west side of the building, the wall along axis 20 failed near two thirds of the height of the first story. The wall flange below the observed failure surface, parallel to axis A, remained nearly intact, showing no clear signs of failure in compression at the base of the first story (Figure 13). The flange ruptured near the end of lap splices.

\section{DAMAGE BETWEEN AXES 24 AND 35}

The area between axes 24 and 35 was altered by rescue operations.

Photos taken before intervention (IDIEM 2010) are shown in Figure 13. Notice that large segments of walls along axes 24 and 35 show no large inclined cracks, nor signs of out-of-plane buckling. The lower half of the west boundary of the solid wall along axis 35 disintegrated at the base of the first story.

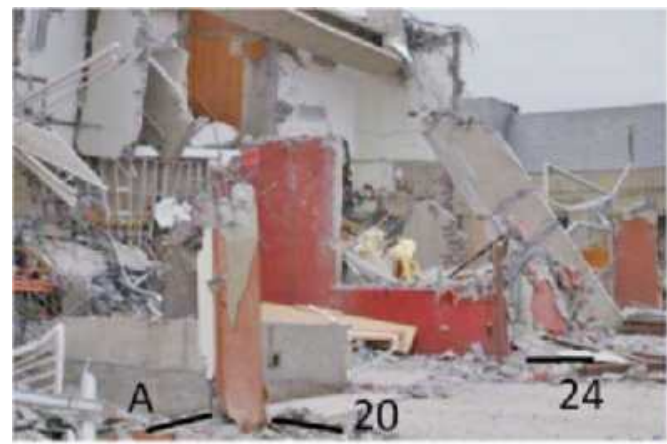

(a)

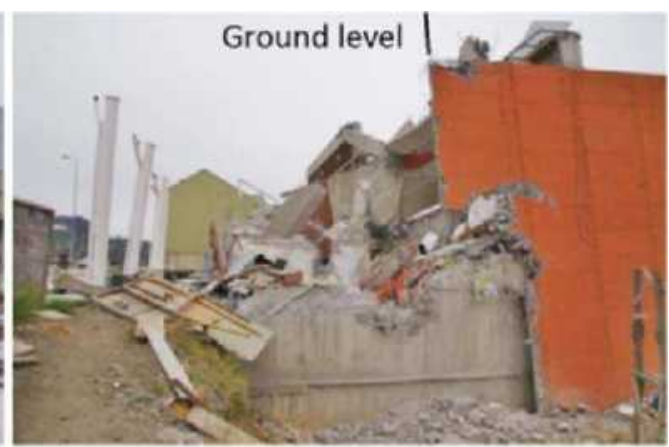

(b)

Figure 13. Damage photos before intervention: (a) Axis 24 (view from northwest); (b) axis 35 (view from south). Photo credit: IDIEM. 


\section{RESPONSE PARAMETERS}

\section{CALCULATED PERIOD}

The computer program SAP2000 (CSI 2000) and the iterative method proposed by Rayleigh (1945) were used to estimate the initial period of the structure. Assumptions and calculation procedures are presented in Appendix B. For the EW direction, the initial period of vibration ${ }^{2}$ for the first mode was computed to be approximately $0.5 \mathrm{~s}$, with a modal participation factor of 1.6.

\section{ESTIMATED DISPLACEMENT DEMAND}

An upper bound to the maximum displacement demand was computed using the method proposed by Sozen (2003):

$$
S_{d}=P G V \times\left(\frac{T}{\sqrt{2}}\right)
$$

where $S_{d}$ is the maximum displacement for a nonlinear single degree-of-freedom system; $P G V$ is the peak ground velocity; and $T$ is the initial period calculated based on uncracked (gross) sections.

The peak ground velocity $(P G V)$ is estimated to have been approximately $0.67 \mathrm{~m} / \mathrm{s}$ (26 in./s; Boroschek et al. 2010). Using this estimate of $P G V$, Equation 1 yields a maximum spectral displacement of approximately $0.25 \mathrm{~m}$ (10 in.), which seems credible given the spectra shown in Appendix A. For a structure able to maintain its integrity, and for a modal participation factor of 1.6 , the associated peak mean drift ratio is $1 \%$.

The calculated estimate of displacement demand suggests that the event that triggered the collapse is not likely to have been associated with large inelastic displacements. The drift ratios at yield vary from approximately $0.5 \%$ to $1 \%$ for structural walls with height-tolength ratios equal to or larger than two (http://nees.org/resources/1683). This observation points to four plausible types of brittle failure or their combinations: failure in shear, compression failure at wall ends, bond failure, and bar fracture. The first type of failure is related to inclined tensile or compressive stresses caused by shear forces. The other types of failure are related to flexure. Conventional limit analyses to estimate whether the strength of the structure was limited by shear or bending are presented in the next sections.

\section{ESTIMATED BASE SHEAR STRENGTH}

The following sections describe estimates obtained using the means of material properties shown in Tables 1 and 2 and conventional methods to estimate shear and flexural strengths.

\section{Limiting Strength in Shear}

The limiting strength in shear was calculated by summing the nominal strengths in shear of all wall segments oriented in the same direction in a given story. A lower bound to the

\footnotetext{
${ }^{2}$ Computed assuming all sections were uncracked initially.
} 
strength in shear of a single wall segment was calculated using the equation shown below (ACI 318 1995):

$$
V_{n}=A_{w}\left(0.17 \sqrt{f_{c}^{\prime}}+\rho_{t} f_{y}\right)
$$

Where $f_{c}^{\prime}$ and $f_{c}$ are in units of $\mathrm{MPa} ; \rho_{t}$ is the horizontal reinforcement ratio; and $A_{w}$ is the area of the web. If $f_{c}^{\prime}$ and $f_{y}$ are expressed in units of psi, Equation $2 \mathrm{a}$ becomes:

$$
V_{n}=A_{w}\left(2 \sqrt{f_{c}^{\prime}}+\rho_{t} f_{y}\right)
$$

The nominal strengths in shear for walls in the first story are associated with base-shear coefficients of approximately 0.7 in the transverse direction and 0.5 in the longitudinal direction (Table 3). The strengths estimated for wall segments in the second story are associated with base-shear coefficients of approximately 0.6 in both directions (Table 3).

The computed ratio of shear demand in the first story to shear demand in the second story is 1.01, assuming a linear distribution of lateral accelerations over building height. For the unlikely condition of a uniform distribution of lateral accelerations, this ratio is 1.08. In the direction of failure, the ratio of resistance to shear in the first story to resistance to shear in the second story is approximately $0.72 / 0.62=1.16$. These ratios would indicate that the structure was more likely to fail "in shear" in the second story. Observations indicating that failure took place in the first story contradict this conclusion and suggest that common methods to estimate the effects of shear forces on the response of walls do not help explain the collapse.

\section{Limiting Strength in Flexure}

Two plausible flexural failure mechanisms were considered. The first failure mechanism was based on the assumption that flexural plastic hinges formed at the bases of the walls in the first story (resembling the observed failure surfaces; Figure 14a). The second failure mechanism was based on the assumption that flexural hinges in walls formed at the bottom of the second story (Figure 14b). The distribution of lateral accelerations over building height was assumed to be linear.

Ten different analyses were made to quantify the sensitivity of the results to differences in analysis assumptions (Table 4). They were made by two engineers working separately to

Table 3. Limiting strength in shear

\begin{tabular}{llccc}
\hline \hline Story & Direction & $\begin{array}{c}\text { Story shear strength } \\
\mathrm{kN}(\mathrm{kip})\end{array}$ & $\begin{array}{c}\text { Base shear strength } \\
\mathrm{kN}(\mathrm{kip})\end{array}$ & $\begin{array}{c}\text { Base-shear } \\
\text { coefficient }^{1}\end{array}$ \\
\hline \multirow{2}{*}{2} & Transverse & $40,600(9,120)$ & $41,000(9,210)^{2}$ & 0.62 \\
& Longitudinal & $42,600(9,580)$ & $43,000(9,680)^{2}$ & 0.65 \\
1 & Transverse & $48,300(10,850)$ & $48,300(10,850)$ & 0.72 \\
& Longitudinal & $35,000(7,870)$ & $35,000(7,870)$ & 0.53 \\
\hline \hline
\end{tabular}

\footnotetext{
${ }^{1}$ Ratio of base shear to total building weight.
}

${ }^{2}$ Story shear strength times ratio of base shear to shear in second story for a linear distribution of acceleration. 


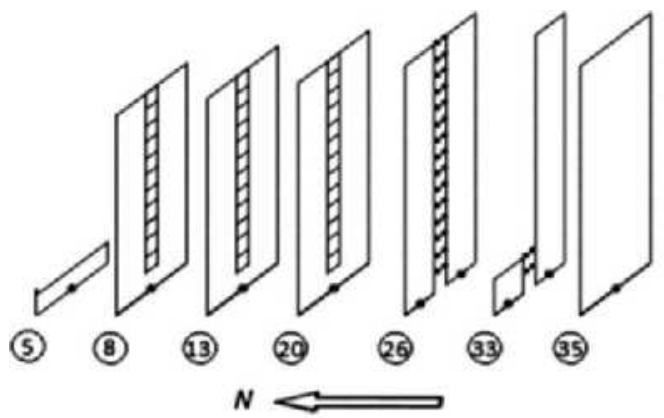

(a)

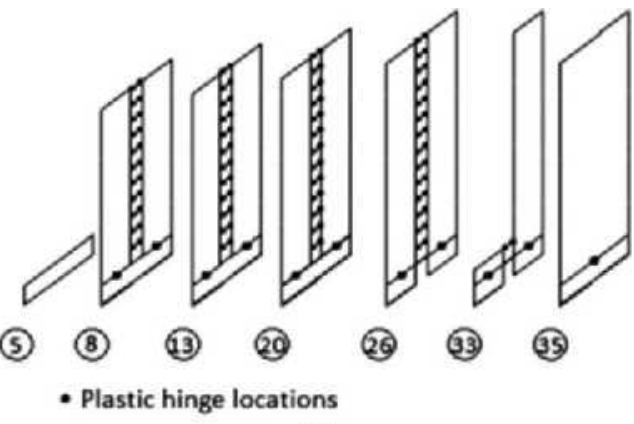

(b)

Figure 14. Limiting mechanisms (flanges not shown for clarity) used in analyses A through D (Table 4): (a) First-story failure mechanism; (b) second-story failure mechanism. Photo credit: E. Fierro and A. Iruretagoyena.

Table 4. Results from limit analyses

\begin{tabular}{|c|c|c|c|c|c|c|c|c|c|c|c|}
\hline \multirow[b]{2}{*}{ Analysis ID } & \multicolumn{10}{|c|}{ Flexure } & \multirow{2}{*}{$\frac{\text { Shear }}{F}$} \\
\hline & \multicolumn{2}{|c|}{ A } & \multicolumn{2}{|c|}{ B } & \multicolumn{2}{|c|}{$\mathrm{C}$} & \multicolumn{2}{|c|}{$\mathrm{D}$} & \multicolumn{2}{|c|}{$\mathrm{E}$} & \\
\hline Assumptions ${ }^{1}$ & $\begin{array}{r}0,1 \\
11\end{array}$ & $\begin{array}{l}3,5 \\
12\end{array}$ & & $\begin{array}{l}3,5 \\
12\end{array}$ & $\begin{array}{c}0,1 \\
5,1\end{array}$ & $\begin{array}{l}3,4 \\
, 12\end{array}$ & $\begin{array}{c}0,1 \\
6,\end{array}$ & $\begin{array}{l}3,4 \\
12\end{array}$ & & $\begin{array}{l}4,7 \\
12\end{array}$ & 13 \\
\hline Force Direction & East & West & East & West & East & West & East & West & East & West & E-W \\
\hline Critical Story $^{2}$ & & & & & & & & & & & \\
\hline 2nd & 0.38 & 0.36 & 0.37 & 0.35 & 0.39 & 0.40 & 0.43 & 0.44 & 0.29 & 0.30 & 0.62 \\
\hline 1 st & 0.51 & 0.50 & 0.49 & 0.48 & 0.47 & 0.52 & 0.48 & 0.53 & 0.36 & 0.40 & 0.72 \\
\hline $\begin{array}{l}\text { Strength of } \\
1 \text { st Story / } \\
\text { Strength of } \\
\text { 2nd Story }\end{array}$ & 1.34 & 1.39 & 1.32 & 1.37 & 1.21 & 1.30 & 1.12 & 1.20 & 1.24 & 1.33 & 1.16 \\
\hline
\end{tabular}

${ }^{1}$ Table 5

${ }^{2}$ Story where walls are assumed to develop plastic hinges at their bases.

check consistency in data entry and they were classified in five groups (named A through E). The assumptions made in each analysis group are described in Table 5. In all analyses, the stress-strain relationship for steel bars was represented by a trilinear relationship. The yield stress for the reinforcement was assumed to be $480 \mathrm{MPa}(70 \mathrm{ksi})$, and the strain at the onset of strain hardening was assumed to be 0.01 . Strain hardening was represented by a straight line with a slope of 4,000 MPa (580 ksi). The stress-strain relationship proposed by Hognestad (1951) was used to represent the response of the concrete in compression. The compressive strength and the limiting strain for the concrete were assumed to be $47 \mathrm{MPa}(6,800 \mathrm{psi})$ and 0.004 respectively. All reinforcement splices were assumed to have no effect on rotational capacity and flexural strength. 
Table 5. Analysis assumptions

\begin{tabular}{|c|c|}
\hline Assumption ID & Description \\
\hline 0 & The failure mechanism was controlled by flexure. \\
\hline 1 & $\begin{array}{l}\text { All sections within each of the contours in Figure } 15 \text { shared the same distribution } \\
\text { of unit strains caused by overturning moments. Perimeter columns were coupled } \\
\text { to adjacent walls by perimeter beams. Figure } 12 \text { suggests these beams worked as } \\
\text { outriggers that made pilasters along axis A work in tension when the building } \\
\text { was subjected to eastward inertial forces. }\end{array}$ \\
\hline 2 & $\begin{array}{l}\text { All sections within each of the contours in Figure } 15 \text {-except the walls within } \\
\text { the area bounded by axes C, G, } 28 \text { and } 30 \text { - shared the same distribution of unit } \\
\text { strains caused by overturning moments. The walls within the area defined by axes } \\
\text { C, G, } 28 \text {, and } 30 \text { acted independently from other sections. Perimeter columns } \\
\text { were coupled to adjacent walls by perimeter beams. Figure } 12 \text { suggests these } \\
\text { beams worked as outriggers that made pilasters along axis A work in tension } \\
\text { when the building was subjected to eastward inertial forces. }\end{array}$ \\
\hline 3 & $\begin{array}{l}\text { The wall segments in the second story that were not supported directly by walls } \\
\text { in the first floor did not resist normal stresses caused by bending. }\end{array}$ \\
\hline 4 & $\begin{array}{l}\text { The wall segments in the first story that were located directly above an opening } \\
\text { in the upper basement did not resist normal stresses caused by bending. }\end{array}$ \\
\hline 5 & $\begin{array}{l}\text { Yield lines formed in slabs where they framed into wall flanges. Effective slab } \\
\text { widths were equal to wall flange widths. }\end{array}$ \\
\hline 6 & $\begin{array}{l}\text { Two yield lines, } 1.2 \mathrm{~m} \text { apart, formed in all slabs from axis } 5 \text { to axis } 34 \text {, } \\
\text { excluding the segment in front of the elevator shaft. }\end{array}$ \\
\hline 7 & $\begin{array}{l}\text { Wall segments and pilasters along a given axis were decoupled from wall } \\
\text { segments and pilasters located along other axes. }\end{array}$ \\
\hline 8 & $\begin{array}{l}\text { Effective wall flanges were limited by lines parallel to the axis of the web and } \\
\text { located at half the distance to the adjacent web axis. }\end{array}$ \\
\hline 9 & $\begin{array}{l}\text { Effective slab widths did not exceed one quarter of the clear span and one half } \\
\text { the sum of the distances from the column/wall axis to the two adjacent axes. }\end{array}$ \\
\hline 10 & $\begin{array}{l}\text { Pilasters along axes } 5,11,17 \text {, and } 24 \text { were integral parts of frames in which } \\
\text { slabs with effective widths given by assumption } 9 \text { acted as beams. }\end{array}$ \\
\hline 11 & $\begin{array}{l}\text { Normal unit strains caused by bending moments vary linearly with distance to } \\
\text { neutral axis. }\end{array}$ \\
\hline 12 & $\begin{array}{l}\text { The axial load (caused by gravity) acting on each cross section was directly } \\
\text { proportional to one half the sum of the distances from column } / \text { wall axis to the } \\
\text { two adjacent axes. The mean unit weight of the building was } 9.8 \mathrm{kN} / \mathrm{m}^{2} \\
(205 \mathrm{psf} \text { ). }\end{array}$ \\
\hline 13 & The failure mechanism was controlled by shear. \\
\hline
\end{tabular}

Representative moment-curvature relationships computed for analysis group A are shown in Figure 16. These relationships suggest that the sections considered could reach yielding before limiting concrete strains would develop.

Limit analyses of the mechanisms with wall hinges in the first story produced base-shear coefficients ranging from 0.36 to 0.53 , depending on the degree of coupling assumed and the 


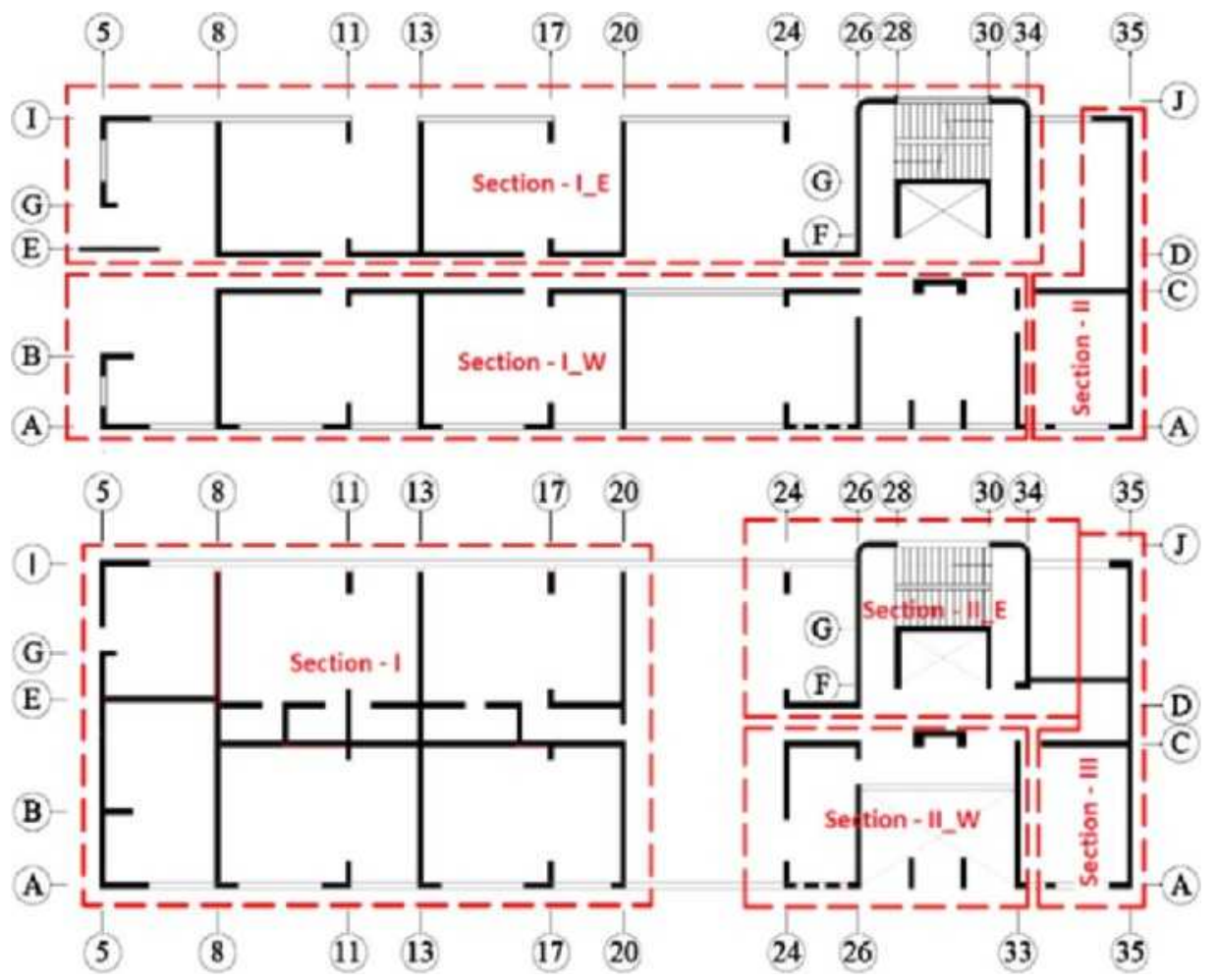

Figure 15. Sections used in analyses A through D (Table 4). Second story is shown above and first story is shown below. Photo credit: E. Fierro and A. Iruretagoyena.

direction of load (Table 4). Limit analyses of the mechanisms with wall hinges in the second story produced base-shear coefficients ranging from 0.29 to 0.44 (Table 4). For all analysis groups and loading directions, independent from the assumptions made, analyses assuming the first story to be the critical story produced results that were consistently larger than the results from analyses assuming that the second story was the critical story. The ratio of the estimated strength of first-story collapse mechanisms to the estimated strength of secondstory collapse mechanisms ranges from 1.12 to 1.39 .

The results of the conventional analyses described indicate that (1) the structure was not deficient in strength; (2) its strength was more likely to be controlled by flexure than by shear, as the estimates of base-shear strength associated with flexure are smaller than the base-shear strength estimated for shear; and (3) a flexural failure mechanism in the second story was more likely than one in the first story. This last inference is in conflict with the field evidence. The photographs and survey information obtained after the 2010 earthquake show clearly that the building failed in the first story (Figure 4). The conflict between the analysis results and the field evidence suggests that the collapse was caused by factors overlooked by conventional analyses similar to those described here. 


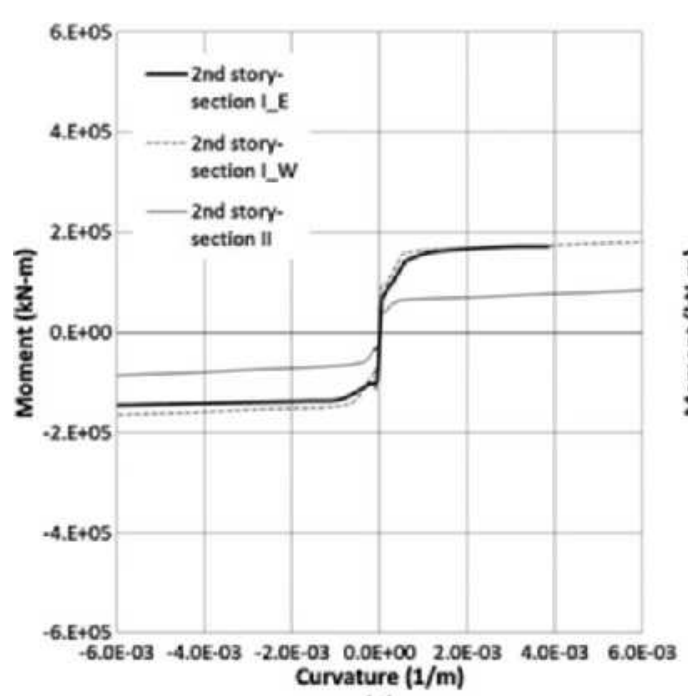

(a)

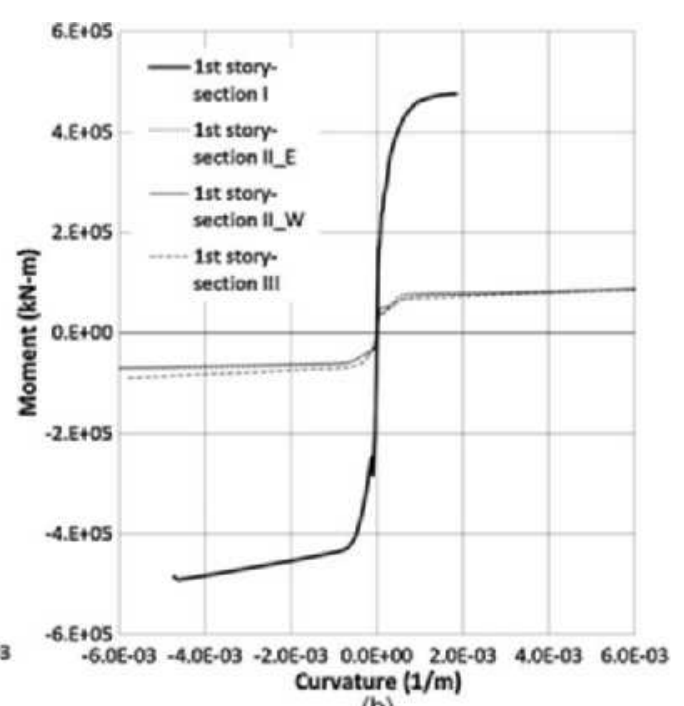

(b)

Figure 16. Moment-curvature diagrams for cross sections in Figure 15 (positive moment corresponds to eastward forces): (a) Second-story walls; (b) first-story walls.

\section{PLAUSIBLE COLLAPSE CAUSES}

The analyses discussed in the previous section ignore collapse mechanisms in which the failure surface starts near one floor and progresses toward the floor above or below. They also ignore mechanisms in which the continuity of the solid walls in the first story is destroyed by local failures. Plausible causes of such local failures are discussed next.

\section{LOCAL FAILURE CAUSED BY SHEAR FORCES}

Moehle et al. (2011) have stated that very large shear forces can develop in "solid walls below or above a row of openings." This statement points directly at the boxed region in Figure 17. This figure shows the forces applied by upper walls (separated by a stack of openings) to a continuous or solid wall at the base. The wall panel directly below the openings is expected to resist fractions of the vertical forces applied by wall boundaries working in tension and compression next to the openings above. These force fractions have opposite sense and result in shear distortion of the wall segment under the openings.

Damage in wall segments located under a "row" or stack of openings was observed in at least two other buildings surveyed after the 2010 Maule Earthquake: Centro Mayor, in Concepción (see Figure 18); and Torre Mayor, in Chillán. In both of these buildings, the boundary reinforcement next to the openings was anchored in the solid wall below the stories with openings (Figure 19). In Alto Río, all boundary reinforcement was anchored into the foundation (two stories below grade; Figure 19). Alto Río also had walls perpendicular to the panel presumed to have failed in shear (along axes $\mathrm{C}$ and $\mathrm{D}$ ). The consequences of these differences deserve careful study. The task is not simple because we have found no experimental data to 


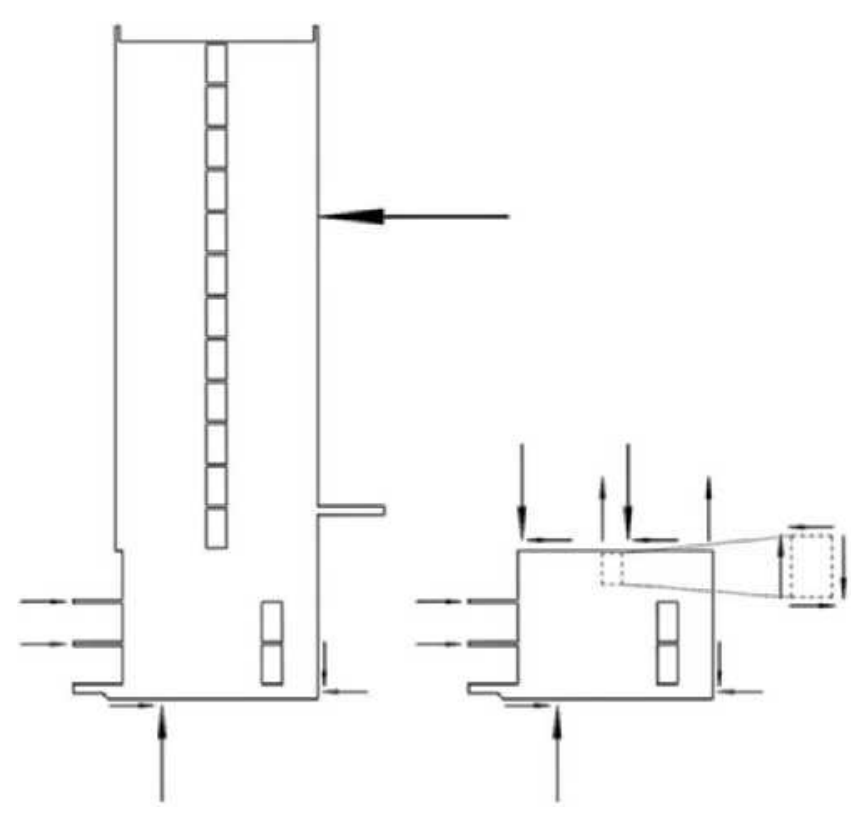

Figure 17. Idealized forces near the base of the wall along axis 13. (Note: the horizontal force at the top of the panel under high shear is assigned to the slab.)

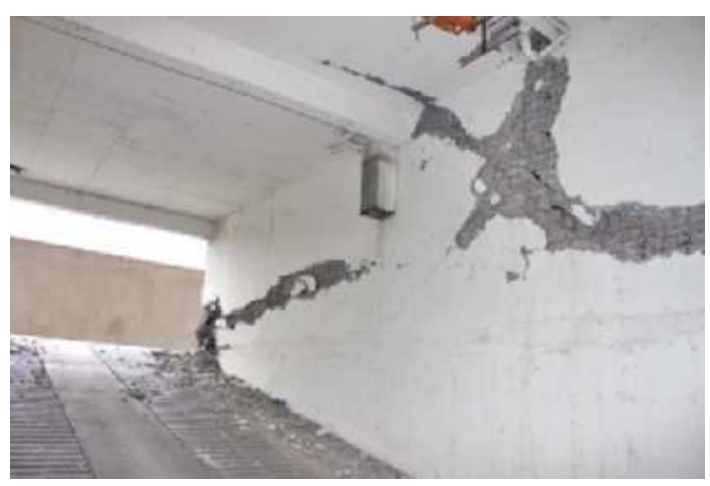

Figure 18. Wall panel with inclined cracks under stack of openings and between anchorage zones of boundary reinforcement from upper stories, Centro Mayor Building, Concepción. Photo credit: J. Moehle, http://nees.org/resources/3111.)

evaluate the strength of a panel under the loading and boundary conditions described. If the wall panels below openings did fail in shear, the first story would cease to be stronger than the second story (as suggested by the simplified analyses presented in the previous section), and the critical section (for flexure) would move to the base of the first story. 


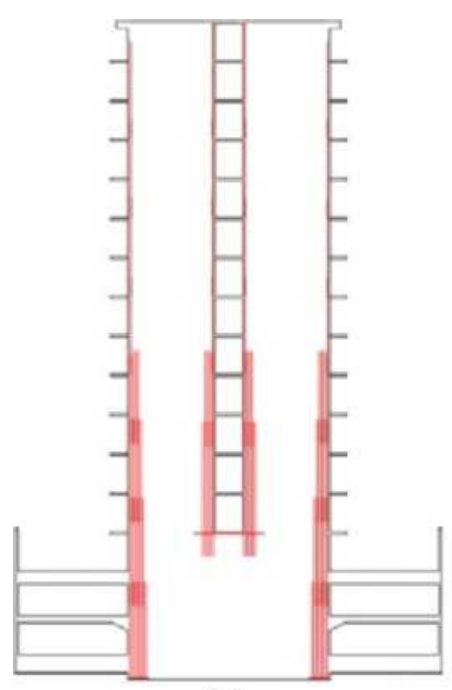

(a)

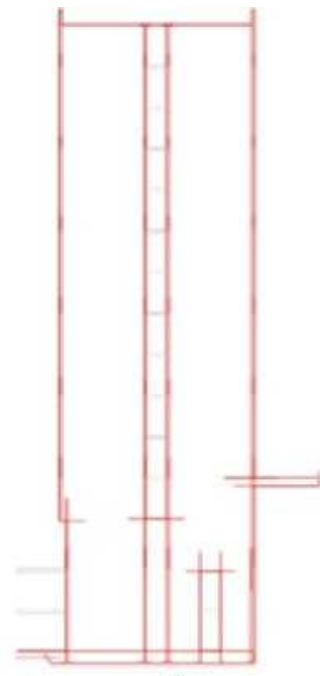

(b)

Figure 19. Distribution of wall boundary reinforcement: (a) Centro Mayor Building; (b) Alto Río Building.

\section{FAILURE CAUSED BY FRACTURE OF REINFORCEMENT}

Wood (1989) developed an index (Equation 3) to determine the vulnerability of wall sections to fracture of the longitudinal reinforcement:

$$
\left(\rho_{t} f_{y}+\frac{P}{A}\right) / f_{c}^{\prime}
$$

where $\rho_{t}$ is the total reinforcement ratio, and $A$ is the cross-sectional area of wall. Wood (1989) suggested that, if this index is less than 0.15, wall longitudinal reinforcement is vulnerable to fracture under displacement reversals in the nonlinear range of response.

The index was less than 0.10 for approximately $50 \%$ of the wall sections in both the first and second stories of Alto Río. This suggests that fracture of the reinforcement could have led to the collapse. Figure 6 shows that bar fractures occurred. But they occurred at the base of the first story rather than at the base of the second story. This fact and the conventional analyses presented suggest that the solid walls in the first story were weakened either by shear failures under openings (as suggested by the model by Moehle et al. 2011), or by bond failures along lap splices (Figure 6), or both.

\section{FAILURE CAUSED BY COMPRESSION}

The conventional limit analyses described here do not identify a compression failure in the first story because they indicate that the second story was weaker in flexure. A weaker second story would have prevented the bending moments acting on the walls in the first story from reaching the levels associated with crushing of the concrete. Nevertheless, it is plausible 
that stress concentrations related to discontinuities may have caused compression failures near the top of first-story walls. Walls with T-shaped sections in the second story had limited ductility (Figure 20) and discontinuities (re-entrant corners, flange cutoffs, and wall openings, Figures 2 and 3) that may have created stress concentrations near their bases.

Figure 20 shows a moment-curvature relationship computed for a section at the base of the second floor. The computed yield $\left(\varphi_{y}=0.0011 / \mathrm{m}\right)$ and limit curvatures $\left(\varphi_{u}=0.0031 / \mathrm{m}\right)$ are sufficient to justify a rotational capacity of at least $1 \%$ on the basis of conventional assumptions (Wallace and Moehle 1992):

$$
\theta=\frac{1}{4} \varphi_{y} h_{w}+\left(\varphi_{u}-\varphi_{y}\right) \frac{l_{w}}{2}=\frac{1}{4} \times 0.001 \frac{1}{m} \times 30.5 m+(0.003-0.001) \frac{1}{m} \times \frac{5.4 m}{2}=1.3 \%
$$

where $h_{w}$ is wall height and $l_{w}$ is wall length in plan.

But the applicability of the method used to arrive at this estimate may be questioned given the limited information available on the capacity of the method to reproduce experimental results and given the presence of discontinuities along axis I. The following discontinuities have received much attention (IDIEM 2010):

1) Pilasters at nodes I-11, I-17, and I-24 had an offset and a change in cross section (Figure 21).

2) Wall and pilaster flanges, and in a number of cases entire pilasters, present in the second and upper stories, did not extend into the first and underground stories (Figures 2 and 3).

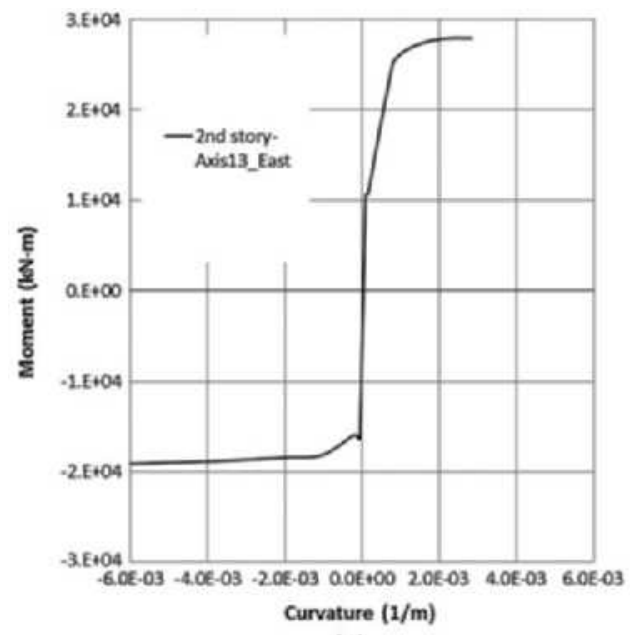

(a)

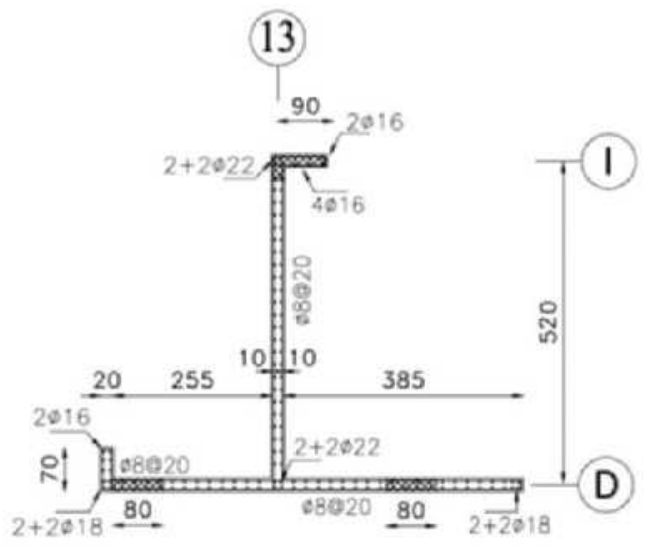

(b)

Figure 20. Wall along Axis 13, base of second story: (a) Computed moment-curvature relationship; (b) cross section (dimensions in $\mathrm{cm}$ ). Notes: Shaded areas were ignored because they were unsupported; positive values correspond to eastward forces; assumed axial load equal to approximately $5 \%$ of the product of concrete strength times gross area (all other required assumptions described in section on limiting flexural strength). 


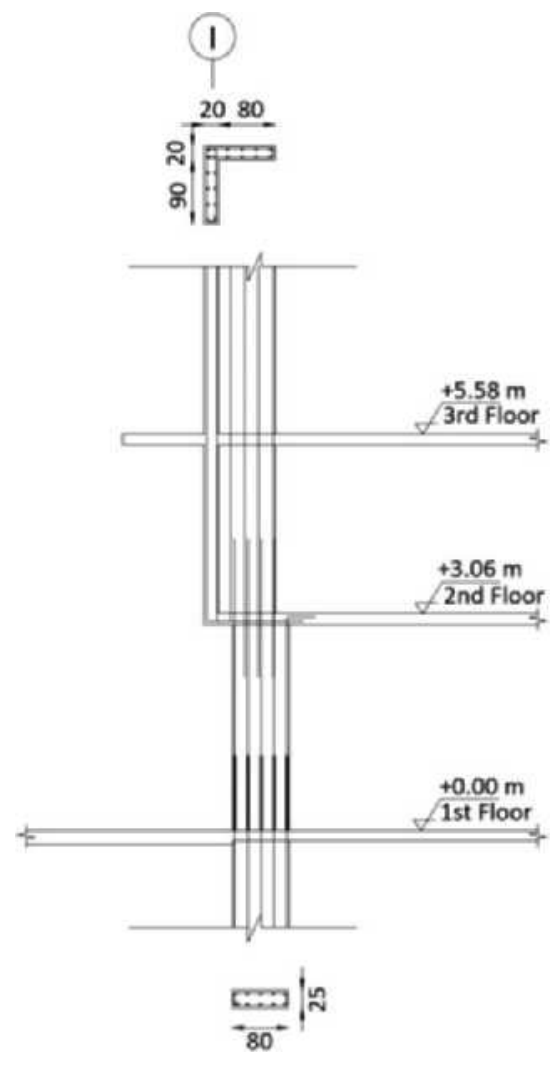

Figure 21. Pilaster offset at I-11, I-17, and I-24 (view from north); cross-sectional dimensions in $\mathrm{cm}$.

It has been suggested (IDIEM 2010) that the discontinuities along axis I and the re-entrant corners and flange cutoffs in walls along axes 8, 13, and 20 caused failure in compression of wall sections near the top of the first story on the east side of the building (Figure 22). This plausible failure is more likely to have led to collapse mechanism II than collapse mechanism I because mechanism II is weaker. But field evidence indicates that mechanism II did not occur. Mechanism I could have governed if the wall segments under hallways were damaged by shear and/or the bases of the first-story walls on the west side of the building were weakened in tension by splice failures at the bottom of the first story.

Wall discontinuities, offsets, and openings were also present on the west side of the building; see the top of the first story at node A-20 in the elevation of axis A (Figure 3) and axis 20 (Figure 7).

Failure of walls by buckling of segments in compression has also been considered as a plausible collapse trigger. Buckling of walls was observed in other buildings in Chile and more recently in New Zealand, after the 2011 Christchurch earthquake. Information on factors that may lead to wall buckling is limited, but available test data (nees.org/resources/1683) suggest that wall buckling follows bar yielding and occurs at mean drift ratios exceeding $2 \%$. 


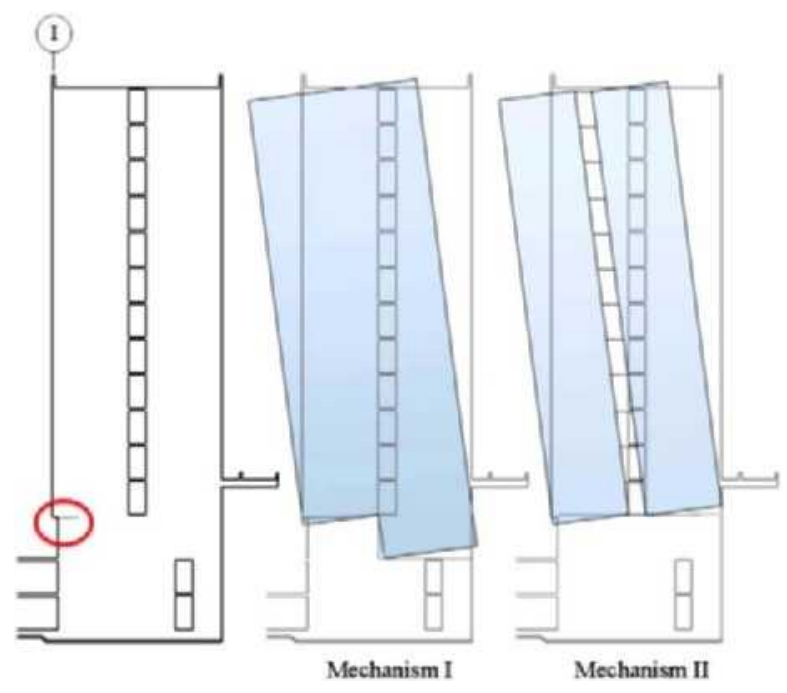

Figure 22. Idealized failure mechanisms associated with a presumed failure caused by geometric discontinuities along axis I.

\section{FAILURE CAUSED BY BOND STRESSES}

Bond failures were observed in lap splices at the base of the first story (Figure 6). It is possible that these failures limited the strength of that story, enabling mechanism I (Figure 22) and/or shifting the critical section to resist overturning moments from the bottom of the second story to the bottom of the first story. The failure of lap splices may also have reduced the effective reinforcement ratio at the base of the structure, making bar fracture at that location more likely. A recent test at the University of Illinois ${ }^{3}$ showed that lap splices in structural walls can cause concentration of strains, leading to bar fracture at the ends of the splices, and that loss of bond in spliced bars and fracture of (other) bars are not mutually exclusive.

It is often argued that bond failure at splices - followed in this case by fracture of the remaining bars - simply leads to rocking, which does not always result in overturning. The criterion proposed by Housner (1963) to evaluate the stability of a rocking block indicates that the building was indeed unlikely to overturn if it had started rocking from rest ${ }^{4}$ and if its base had retained its integrity. Nevertheless, (1) it is uncertain that the base of the building would have endured the impacts associated with rocking, and (2) rocking response is sensitive to small variations in initial conditions (Nasi 2011). Past experience with rocking blocks

\footnotetext{
${ }^{3}$ https:/catalyst.uw.edu/workspace/delehman/9203/62137: Anna Birely Planar Walls General Exam.

${ }^{4}$ According to Housner (1963), an aspect ratio less than $\frac{\sqrt{g \cdot R}}{S_{v}}$ indicates low probability of overturning during rocking ( $R$ is distance from the toe to the centroid, and $S_{v}$ is spectral velocity in the region of nearly constant velocity response). The aspect ratio of Alto Río was approximately 3, which is less than $\frac{\sqrt{g \cdot R}}{S_{V}}=5.8$ (for $R=\sim 20 \mathrm{~m}$ and $S_{v}=\sim 2.4 \mathrm{~m} / \mathrm{s}$ (Nasi 2011). Nasi (2011) observed the probability of overturning in rocking concrete blocks with aspect ratios less than $\frac{\sqrt{g \cdot R}}{S_{V}}$ to be approximately $10 \%$.
} 
may not apply to cases in which the rocking object is given an initial impulse (caused by the failure of splices and fracture of bars).

It is plausible that, if the building rocked, the walls at the base of the structure shifted off the basement walls that supported them. Several factors could have caused this shift: (1) failure of the wall toes in compression, (2) ground motion in the longitudinal direction, (3) vertical acceleration, and/or (4) torsion caused by the solid wall along axis 35 (Figure 2). If the first-story walls shifted off their supports, they must have punched through the $15 \mathrm{~cm}$ (6 in) thick slab at grade level, causing the observed overturning.

Walls in the first story had lap splices in all main boundary reinforcement and vertical web reinforcement. Walls in the second story had similar splices in one third of the main boundary reinforcement. Lengths of lap splices specified in structural drawings are listed in Table 6. These lap lengths are within current U.S. practice. But (1) current U.S. standards are based mostly on tests of lap splices shorter than 40 bar diameters, (2) mean unit bond strength decreases with splice length (within the lengths that have been tested so far), and (3) the clear spacing between the bars was observed to be less than 1 bar diameter in surviving lap splices (Figure 23).

Figure 24 shows that, for splices with more than 40 bar diameters in length and no more than 1.5 bar diameters in clear cover (or 3 bar diameters in clear spacing), and considering the scatter in the data, it is possible to find cases in which the static bond strength-for monotonic loads-is less than $\left({ }^{1} / 3\right) \sqrt{f_{c}^{\prime}}$ in $\mathrm{MPa}\left(4 \sqrt{f_{c}^{\prime}}\right.$ in psi).

The data in Figure 24 come from test of lap splices with the following properties (ACI 408 2001, Seliem et al. 2009):

Clear cover or half clear spacing:

Concrete strength:

Transverse reinforcement:

0.5 to 1.5 bar diameters

Bar diameter:

18 to $69 \mathrm{MPa}(2,600$ to $10,000 \mathrm{psi})$

none

10 to $36 \mathrm{~mm}(3 / 8$ to $11 / 8 \mathrm{in})$

The mean bond stress required to develop the yield stress of the bars in Alto Río (which had lap splices with lengths of approximately $60 d_{b}$ ) was nearly $4 \sqrt{f_{c}^{\prime}}$ (in psi):

$$
\frac{\mu}{\sqrt{f_{c}^{\prime}}}=\frac{d_{b} \times f_{y}}{4 \times L_{d} \times \sqrt{f_{c}^{\prime}}}=\frac{1 \mathrm{in} \times 70,000 \mathrm{psi}}{4 \times 56 \mathrm{in} \times \sqrt{6800} \mathrm{psi}}=\sim 4
$$

Table 6. Splice lengths of reinforcing bars in the first story

\begin{tabular}{llllll}
\hline \hline Bar type & $\Phi 8 \mathrm{~mm}$ & $\Phi 16 \mathrm{~mm}$ & $\Phi 18 \mathrm{~mm}$ & $\Phi 22 \mathrm{~mm}$ & $\Phi 25 \mathrm{~mm}$ \\
Splice lengths ${ }^{1,2} \mathrm{~mm}$ (in.) & $500(20)$ & $900(35)$ & $1050(40)$ & $1250(50)$ & $1400(55)$ \\
Ratios of splice lengths to bar diameters & 63 & 56 & 58 & 57 & 56 \\
\hline \hline
\end{tabular}

${ }^{1}$ As specified in drawings dated November 2006.

${ }^{2}$ The specified splice lengths were confirmed in the field where possible. 


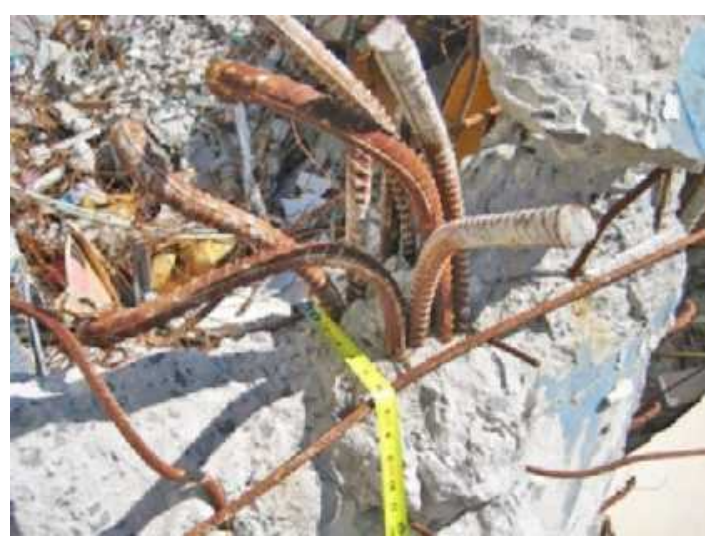

Figure 23. Surviving lap splices.

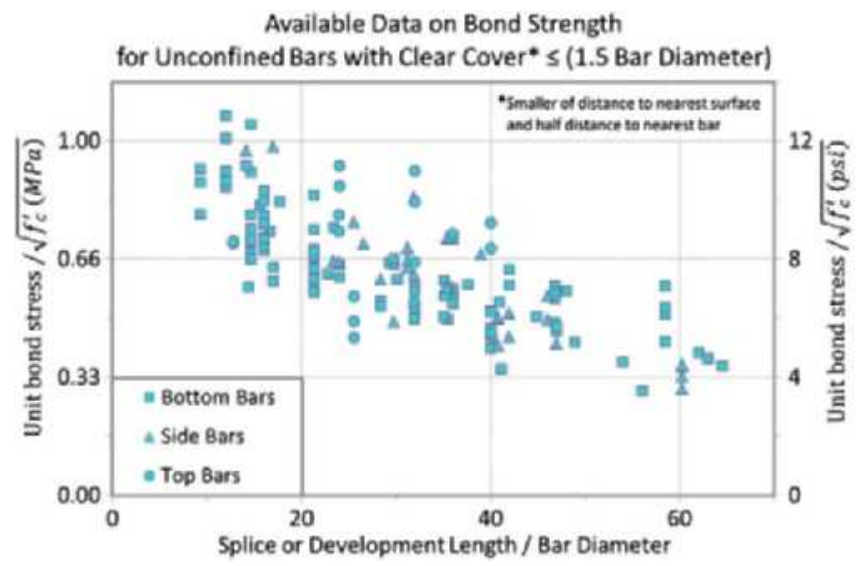

Figure 24. Monotonic, static bond strength of unconfined deformed bars with relatively small cover (data reported by ACI 4082001 and Seliem et al. 2009).

This estimate and the data in Figure 24 suggest that the hypothesis that bond failure took place in lap splices is plausible. The measurements in Figure 24 were obtained in static and monotonic tests. In Alto Río, the bars resisted dynamic load reversals.

Failures of lap splices meeting modern standards have been reported for dynamic loads before (Kilic and Sozen 2003, Kayen et al. 2007). Splice failures and failures at points where bars were cut off were observed by the writers in at least eight other buildings in Chile, among them, Acapulco, Marina Real, Festival, Bahía, and Toledo, all in Viña del Mar; Emerald in Santiago; and Centro Mayor in Concepción. ${ }^{5}$

${ }^{5}$ Details about these buildings are to be published at nees.org. 
The performance of the lap splices may have also been affected adversely by compressive stress concentrations and concrete crushing not revealed by analyses based on conventional assumptions about the distribution of strains at the bases of structural walls. It has also been said that construction errors contributed to the collapse (IDIEM 2010).

\section{SUMMARY}

In the preceding sections four types of local failure that may have led to collapse described: (A) shear failure of the wall panels under stacks of wall openings (hatched area in Figure 25); (B) fracture of bars at sections with low reinforcement ratios (marked by zig-zag lines in Figure 25); (C) stress concentration at re-entrant corners and flange cutoffs in walls (dotted areas in Figure 25), and (D) failure of unconfined lap splices. None of these local failures explains by itself the collapse and the state of the structure after the collapse. Four combinations of failure types A through D are listed in Table 7. It is plausible that any of these combinations may have led to the collapse and the state of the structure after the collapse. At this point the evidence is not sufficient to pick one combination with confidence. But the field evidence does show two clear facts: on the west side of the building the failure surface was close to the base of first-story walls and all the vertical reinforcement on that side of the building failed in tension (failure cause B) or bond (failure cause D).

The discussions presented focus on walls with U-shaped elevations (along axes 8, 13, 20) because these walls dominated the response of the north half of the building. The solid wall along axis 35 is likely to have dominated the response of the south half of the building.
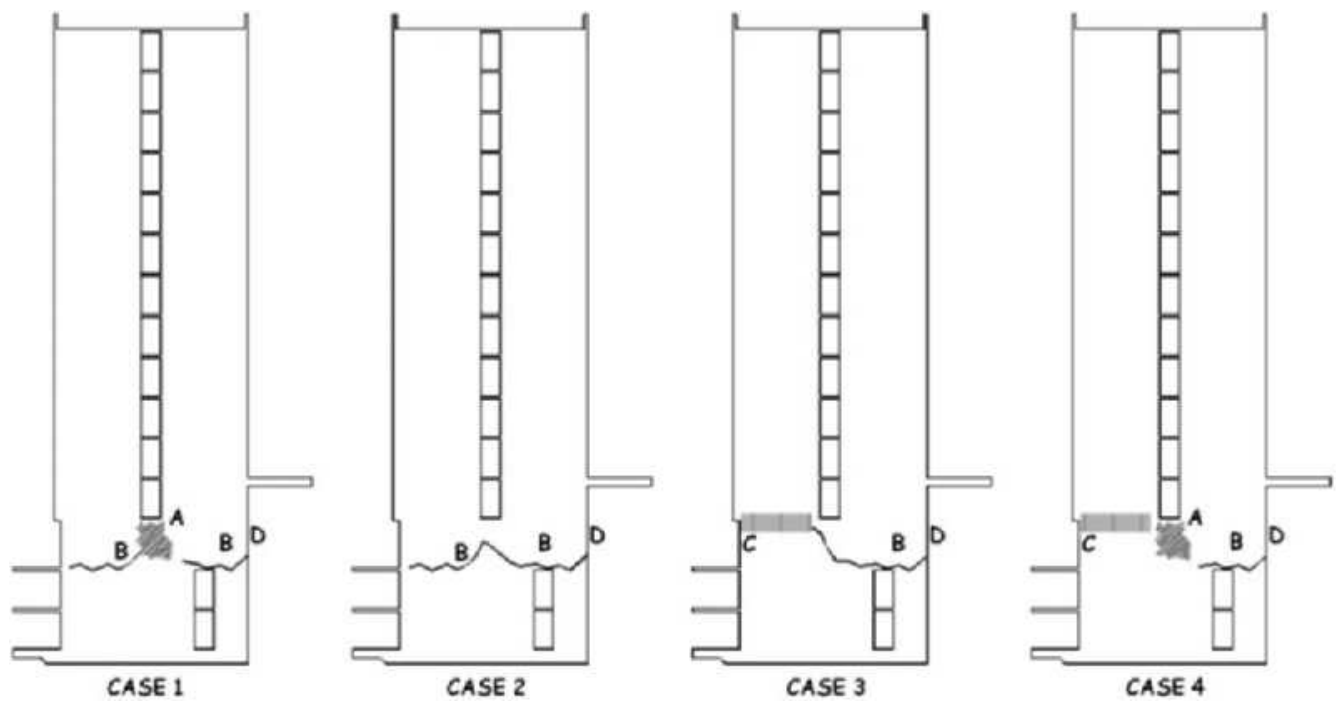

Figure 25. Combinations of local failures that may have led to collapse. 
Table 7. Combinations of local failures that may have led to collapse

\begin{tabular}{l|c|c|c|c|l}
\hline \hline & \multicolumn{3}{|c|}{ Failure Cause } & \\
\hline Case & A & B & C & D & Comments \\
\hline 1 & Shear & Fracture & Compression & Splices & \\
\hline 2 & & & & $\begin{array}{l}\text { Destruction of the hatched region A in Figure 25 } \\
\text { could be followed by fracture of the reinforcement } \\
\text { (B) and/or the failure of the splices (D) leading to } \\
\text { collapse. This combination would require severe } \\
\text { distortion of the slabs connecting the walls above } \\
\text { the second story. The state of the north facade in } \\
\text { Figure 4 does not indicate that such distortion } \\
\text { occurred. }\end{array}$ \\
\hline \hline & & & & $\begin{array}{l}\text { This combination (bar fracture and splice failure) } \\
\text { would explain the overturning of the building and } \\
\text { its state after collapse. An argument against it is } \\
\text { that other buildings with similar amounts of } \\
\text { vertical reinforcement and unconfined splices did } \\
\text { not fail. }\end{array}$ \\
\hline & & & & $\begin{array}{l}\text { Compressive failure of the dotted region C in } \\
\text { Figure 25 may have been followed by failures B } \\
\text { and D as the building pivoted about NS walls } \\
\text { (Figure 2). In buildings with similar structural } \\
\text { layouts in Viña del Mar (Toledo building) and } \\
\text { Santiago (Emerald building), compression failures } \\
\text { in the stems of T-shaped walls and splice failures } \\
\text { on stems of T-shaped walls on the opposite side } \\
\text { the building were observed. }\end{array}$ \\
\hline
\end{tabular}

\section{CONCLUSIONS}

The Alto Río Building, a reinforced concrete residential building with 15 stories above grade and structural walls occupying approximately $7 \%$ of the typical floor area, collapsed during the 27 February 2010 Maule, Chile, earthquake. 
The analyses presented show that, had the building retained its integrity, the maximum displacement demand would have been modest (causing a mean drift ratio of approximately $1 \%$ ), suggesting that the failure mechanism was brittle.

Four factors that may have contributed to the collapse were discussed: (A) shear forces under stacks of wall openings, (B) fracture of verticle bars at sections with low reinforcement ratios $(0.5 \%$ in average $),(\mathrm{C})$ compressive stress concentrations at re-entrant corners and flange cutoffs in walls, and (D) bond failure along unconfined lap splices. The actual sequence of events leading to the collapse and the roles played by these factors are unknown. What is known is that the overturning that took place did require the failure in tension or bond (factors $\mathrm{B}$ and $\mathrm{C}$ ) of at least $50 \%$ of the vertical reinforcement at the base of the building. To avoid such collapses in building structures that rely on walls for earthquake resistance, the cited four factors should be considered carefully. It is also evident that the current state of the art is inadequate to make a confident identification of the driving failure mechanism for the Alto Río Building.

\section{ACKNOWLEDGMENTS}

The work described here was made possible by support from The National Science Foundation (award number CMMI 1034834) and through the help of Patricio Bonelli, Enrique Villalobos, Gabriel Alarcón, Mete Sozen, Jack Moehle, Jeff Rautenberg, J. Paul Smith, Eduardo Fierro, and Cynthia Perri. We are also grateful for the many comments and ideas generously provided by the reviewers and editors of Earthquake Spectra during the preparation of this manuscript.

\section{APPENDIX A: RESPONSE SPECTRA}

The shapes of ground acceleration histories recorded at the station of Colegio Inmaculada Concepción (Figure A1) were reported by Boroschek et al. (2010). The records of ground motion were released by University of Chile in October 2011 (Fcfm 2011). Released ground motion records were used to derive linear and nonlinear displacement response spectra (Figures A2 and A3). The design displacement spectra defined by the Chilean code NCh433.Of96 are also shown in Figure A2.

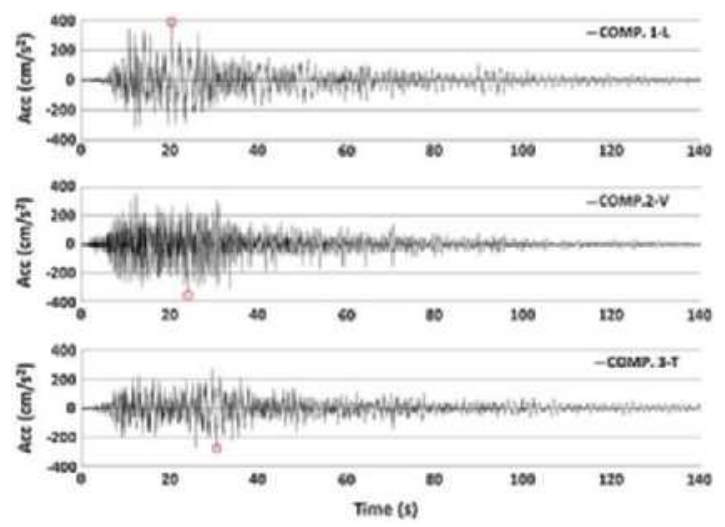

Figure A1. Acceleration history recorded at Colegio Inmaculada Concepción for the 2010 Maule earthquake. 1-L, 2-V, and 3-T are corresponding to the longitudinal (60-degree), vertical, and transverse (150-degree) directions of the strong-motion equipment (Boroschek et al. 2010). 


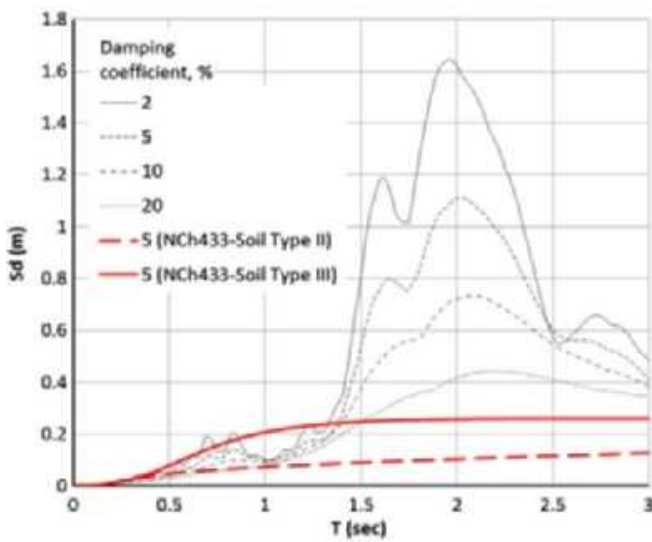

(a)

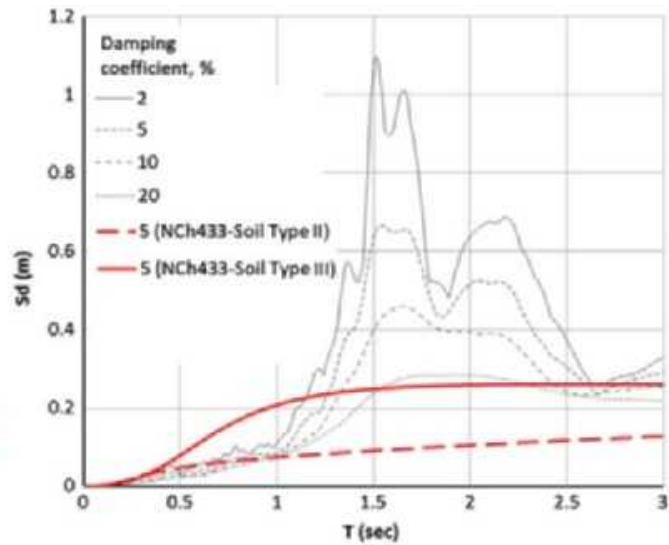

(b)

Figure A2. Linear displacement spectra derived for ground motion records from station Colegio Inmaculada Concepción (García 2008) and design displacement spectra from Chilean Code NCh433.Of96: (a) 60-degree (longitudinal) component; (b) 150-degree (transverse) component.

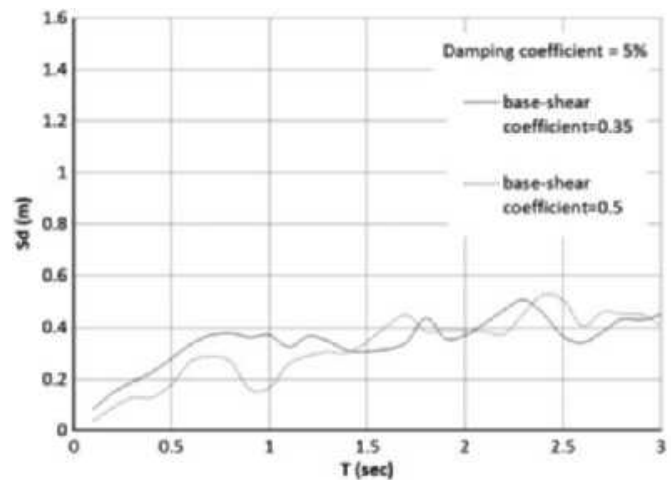

(a)

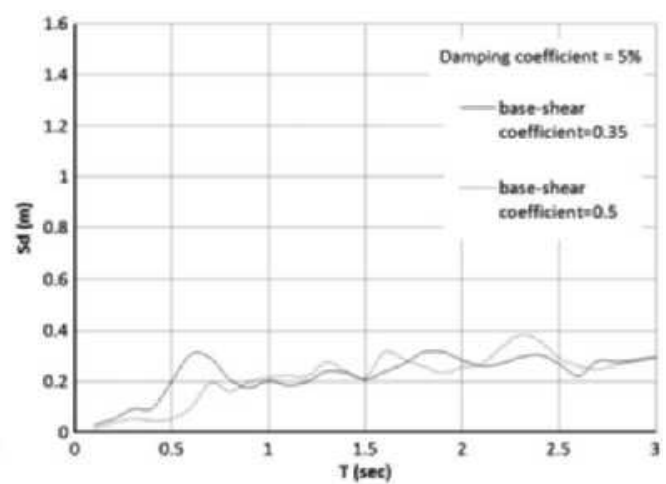

(b)

Figure A3. Nonlinear displacement spectra (for elastoplastic oscillators) derived for ground motion records from station Colegio Inmaculada Concepción (Earthquake Solutions 2010): (a) 60-degree (longitudinal) component; (b) 150-degree (transverse) component.

Nonlinear displacement spectra (Figure A3) computed for the ground motion records show that the level of amplification observed for linear response for periods between $1.4 \mathrm{~s}$ and $2.5 \mathrm{~s}$ does not occur for nonlinear response (Song 2011).

\section{APPENDIX B: PERIOD COMPUTATION}

The computer program SAP2000 (CSI 2000) and the iterative method proposed by Rayleigh (1945) were both used to estimate the initial period of the structure. The structure was assumed linear-elastic and fixed at the base of the first story. Masses were assumed to be 
concentrated at floor levels and calculated based on a uniformly distributed dead load of $9.8 \mathrm{kN} / \mathrm{m}^{2}$ (205 psf). The mass of an extension of the second floor that acted as a canopy was added to the mass of the second floor. Weights for each level are listed in Table B1. The modulus of elasticity of all elements was assumed to be $32,400 \mathrm{MPa}(4,700 \mathrm{ksi})$ and the Poisson's ratio was assumed to be 0.2. The initial period of the building was determined using stiffness properties based on the gross sections of the walls.

\section{3-D MODEL IN SAP2000}

Because of the intricacy of the structural walls in the building, a 3-D model was developed in SAP2000 (Figure B1). Structural walls were modeled using shell area sections. The membrane and bending thicknesses for the wall sections were defined as $200 \mathrm{~mm}$ (8 in.). Flat slabs were also modeled as shell area sections with a thickness of $150 \mathrm{~mm}(6 \mathrm{in}$.).

\section{RAYLEIGH'S METHOD}

The numerical procedure proposed by Rayleigh (1945) was also used to estimate the initial period of the structure in its transverse direction. The structure was idealized as a non-prismatic cantilever column. The base of the cantilever was assumed to represent the

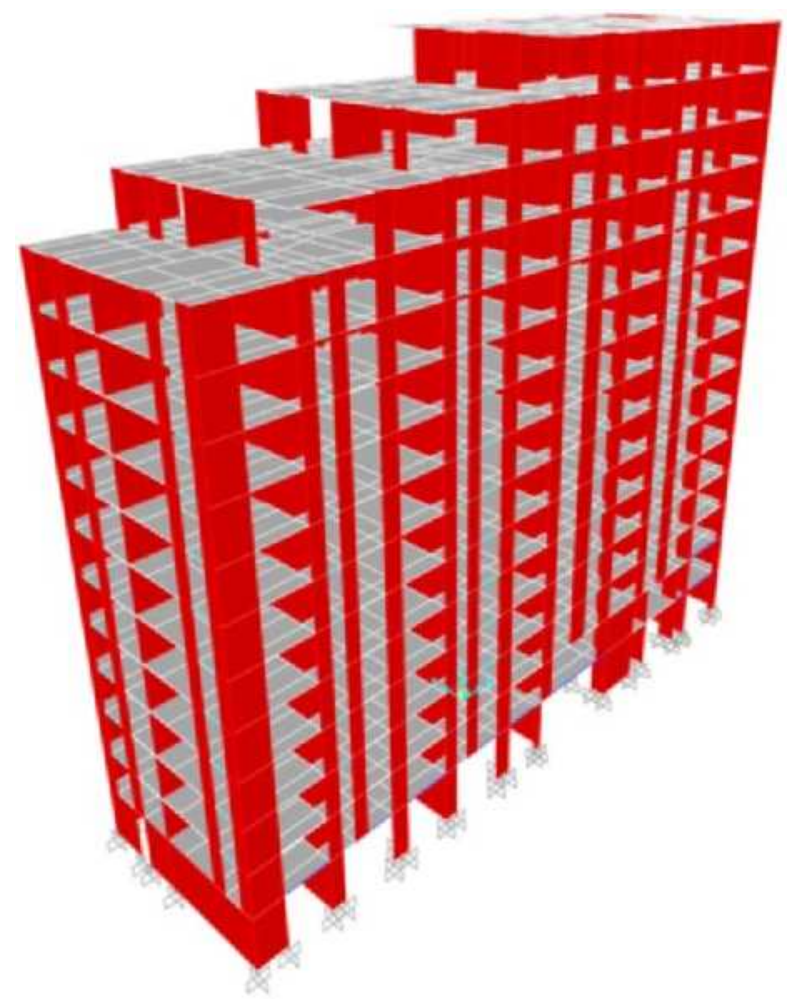

Figure B1. 3-D model in SAP2000. 
first story. The moment of inertia of the base was computed as the moment of inertia of the entire cross section at the first floor about an axis parallel to the longitudinal direction (NS) and passing through the cross-sectional centroid. The moments of inertia of the upper stories were computed as the sum of (1) the centroidal moment of inertia of the total crosssectional area between axes $\mathrm{A}$ and $\mathrm{C}$ and (2) the centroidal moment of inertia of the total cross-sectional area between axes D and J (Figure 15). Deformations related to shear were ignored. Computed moments of inertia for each story are shown in Table B1.

Table B1. Weight and moment of inertia for each story

\begin{tabular}{|c|c|c|c|c|c|}
\hline $\begin{array}{l}\text { Floor } \\
\text { level }\end{array}$ & $\begin{array}{l}\text { Height, } \\
\text { m (ft) }\end{array}$ & $\begin{array}{l}\text { Weight, } \\
\text { kN (kip) }\end{array}$ & $\begin{array}{l}\text { Normalized } \\
\text { weight }\end{array}$ & $\begin{array}{c}\text { Moment of } \\
\text { inertia, } \mathrm{m}^{4}\left(\mathrm{ft}^{4}\right)\end{array}$ & $\begin{array}{c}\text { Normalized momen } \\
\text { of inertia }\end{array}$ \\
\hline \multirow[t]{2}{*}{ Roof } & $38.34(125.8)$ & $2310(520)$ & 0.50 & & \\
\hline & & & & $88(10200)$ & 0.34 \\
\hline \multirow[t]{2}{*}{15} & $35.82(117.5)$ & $2920(660)$ & 0.63 & & \\
\hline & & & & $117(13500)$ & 0.45 \\
\hline \multirow[t]{2}{*}{14} & $33.30(109.3)$ & $3830(860)$ & 0.82 & & \\
\hline & & & & $151(17500)$ & 0.58 \\
\hline \multirow[t]{2}{*}{13} & $30.78(101.0)$ & $4650(1050)$ & 1.00 & & \\
\hline & & & & $185(21400)$ & 0.71 \\
\hline \multirow[t]{2}{*}{12} & $28.26(92.7)$ & $4650(1050)$ & 1.00 & & \\
\hline & & & & $185(21400)$ & 0.71 \\
\hline \multirow[t]{2}{*}{11} & $25.74(84.4)$ & $4650(1050)$ & 1.00 & & \\
\hline & & & & $185(21400)$ & 0.71 \\
\hline \multirow[t]{2}{*}{10} & $23.22(76.2)$ & $4650(1050)$ & 1.00 & & \\
\hline & & & & $185(21400)$ & 0.71 \\
\hline \multirow[t]{2}{*}{9} & $20.70(67.9)$ & $4650(1050)$ & 1.00 & & \\
\hline & & & & $185(21400)$ & 0.71 \\
\hline \multirow[t]{2}{*}{8} & $18.18(59.6)$ & $4650(1050)$ & 1.00 & & \\
\hline & & & & $185(21400)$ & 0.71 \\
\hline \multirow[t]{2}{*}{7} & $15.66(51.4)$ & $4650(1050)$ & 1.00 & & \\
\hline & & & & $185(21400)$ & 0.71 \\
\hline \multirow[t]{2}{*}{6} & $13.14(43.1)$ & $4650(1050)$ & 1.00 & & \\
\hline & & & & $185(21400)$ & 0.71 \\
\hline \multirow[t]{2}{*}{5} & $10.62(34.8)$ & $4650(1050)$ & 1.00 & & \\
\hline & & & & $185(21400)$ & 0.71 \\
\hline \multirow[t]{2}{*}{4} & $8.10(26.6)$ & $4650(1050)$ & 1.00 & & \\
\hline & & & & $185(21400)$ & 0.71 \\
\hline \multirow[t]{2}{*}{3} & $5.58(18.3)$ & $6510(1460)$ & 1.40 & & \\
\hline & & & & $178(20600)$ & 0.68 \\
\hline \multirow[t]{2}{*}{2} & $3.06(10.0)$ & $4650(1050)$ & 1.40 & & \\
\hline & & & & $261(30200)$ & 1.00 \\
\hline 1 & $0.00(0.00)$ & 0.00 & 0.00 & & \\
\hline
\end{tabular}




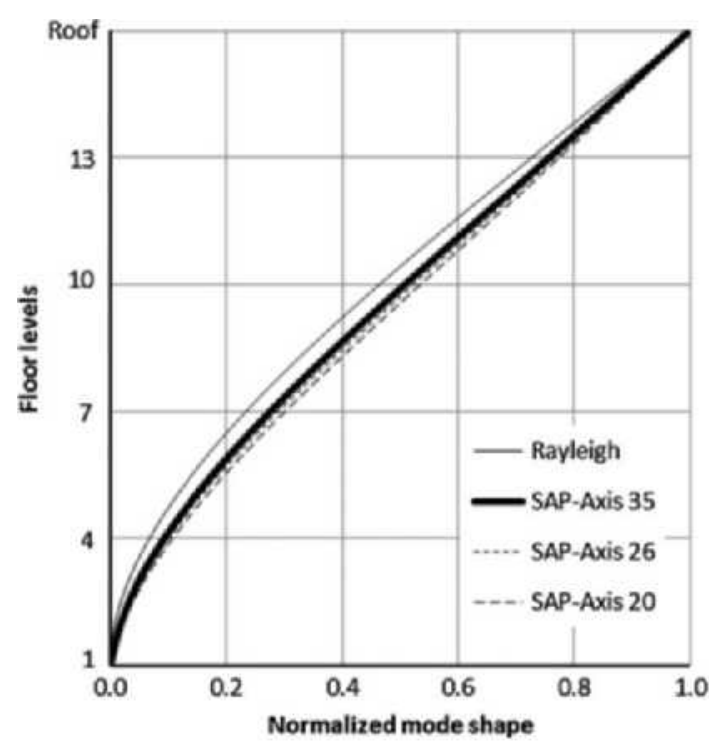

Figure B2. Computed mode shapes.

The initial period of vibration for the building was computed to be approximately $0.5 \mathrm{~s}$. Normalized mode shapes computed through both methods are compared in Figure B2. The computed modal participation factor is 1.6 for the first mode of vibration in the EW direction.

\section{REFERENCES}

American Concrete Institute (ACI 318), 1995. Building Code Requirements for Structural Concrete (ACI 318-95) and Commentary (ACI 318R-95), American Concrete Institute, Farmington Hills, MI, 369 pp.

American Concrete Institute (ACI 408), 2001. Development and Splice Lengths of Uncoated Bars, available at https://nees.org/groups/bond_rc/wiki/MainPage.

Boroschek, R., Soto, P., and León, R., 2010. Maule Region Earthquake February 27, 2010 $M w=8.8$, RENADIC Report 10/08, Faculty of Mathematics and Physical Sciences, Civil Engineering Department, University of Chile, www.terremotosuchile.cl/red_archivos/ RENAMAULE2010IR2.pdf, 100 pp.

Centro de Investigación, Desarrollo e Innovación de Estructuras y Materiales (IDIEM), 2010. Peritaje Estructural Edificio Alto Río Ciudad de Concepción, Informe $N^{\circ} 612$, Centro de Investigación, Desarrollo e Innovación de Estructuras y Materiales, Universidad de Chile, Santiago, Chile (in Spanish).

Computers and Structures, Inc. (CSI), 2000. SAP2000: Structural Analysis Program, version 14, Computers and Structures, Inc., Berkeley, CA. 
Earthquake Solutions, 2010. Bispec 2.03: Nonlinear Spectral Analysis Software, Earthquake Solutions, Monrovia, CA.

Facultad de Ciencias Físicas y Matemáticas (Fcfm), 2011. Terremoto del Maule, Facultad de Ciencias Físicas y Matemáticas, Universidad de Chile, available at http://terremotos.ing. uchile.cl./registros/164 (in Spanish).

García, L. E., 2008. Spector 2008, Universidad de Los Andes, Bogotá, Colombia.

Hognestad, E., 1951. A Study of Combined Bending and Axial Load in Reinforced Concrete Members, Bulletin 399, University of Illinois Engineering Experiment Station, Urbana, IL, $128 \mathrm{pp}$.

Housner, G. W., 1963. The behavior of inverted pendulum structures during earthquakes, Bulletin of the Seismological Society of America 53, 403-417.

Instituto Nacional de Normalización (INN), 1996. Earthquake Resistant Design of Buildings, Official Chilean Standard NCh433.Of96, Santiago, Chile, 40 pp. (in Spanish).

Instituto Nacional de Normalización (INN), 2006. Steel: Hot Rolled Bars for Reinforced Concrete, Official Chilean Standard NCh204-2006, Santiago, Chile, 22 pp. (in Spanish).

Japan Science and Technology Agency and Japan International Cooperation Agency through the Project of Science and Technology Research Partnership for Sustainable Development (JST-JICA SATREPS), 2010. 2010 Chile Earthquake and Tsunami Technical Report, Peru Project Chile Earthquake Field Investigation Team, Japan, 51 pp.

Kayen, R., et al., 2007. Preliminary Observations on the Niigata-Chuetsu Oki, Japan, Earthquake of July 16, 2007, Learning From Earthquakes Program, Earthquake Engineering Research Institute, 12 pp., available at http://www.eeri.org/lfe/pdf/japan_niigata_chuetsu_ oki_eeri_preliminary_report.pdf (last accessed 11 March 2011).

Kilic, S. A., and Sozen, M. A., 2003. Evaluation of Effect of August 17, 1999, Marmara Earthquake on Two Tall Reinforced Concrete Chimneys, ACI Structural Journal, vol. 100, No. 3, pp. 357-364.

Moehle, J. P., Ghodsi, T., Hooper, J. D., Fields, D. C., and Gedhada, R., 2011. Seismic Design of Cast-in-Place Concrete Special Structural Walls and Coupling Beams, NEHRP Seismic Design Technical Brief No. 6, NIST, U.S. Department of Commerce, 26 pp.

Nasi, K., 2011. Stability of Rocking Structures, M.S. Thesis, Purdue University, West Lafayette, IN.

Ramírez, P., and Vivallos, J., 2009. Microzonificación Sísmica de la Ciudad de Concepción, Chile, in XII Congreso Geológico Chileno, Santiago, Chile.

Rayleigh, J. W. S., 1945. The Theory of Sound, Dover Publications, New York, 480 pp.

Seliem, H. M., Hosny, A., Rizkalla, S., Zia, P., Briggs, M., Miller, S., Darwin, D., Browning, J., Glass, G. M., Hoyt, K., Donnelly, K., and Jirsa, J. O., 2009. Bond characteristics of ASTM A1035 steel reinforcing bars, ACI Structural Journal 106, 530-539.

Song, C., 2011. The Collapse of the Alto Río Building during the 27 February 2010 Maule, Chile, Earthquake, M.S. Thesis, Purdue University, West Lafayette, IN.

Sozen, M. A., 2003. The velocity of displacement, in Proceedings, the NATO Science for Peace Workshop on Seismic Assessment and Rehabilitation of Existing Buildings, S. T. Wasti and G. Ozcebe (editors), Izmir, Turkey, 11-28. 
U.S. Geological Survey (USGS), 2010. USGS Earthquake Hazards Program: Magnitude 8.8 Offshore Bio-Bio, Chile, available at earthquake.usgs.gov/earthquakes/eqinthenews/2010/ us2010tfan/ (last accessed 11 March 2011).

Wallace, J. W., and Moehle, J. P., 1992. Ductility and detailing requirements of bearing wall buildings, ASCE Journal of Structural Engineering 118, 1625-1644.

Wood, S. L., 1989. Minimum tensile reinforcement requirements in walls, ACI Structural Journal 86, 582-591.

(Received 25 March 2011; accepted 14 May 2012) 